\title{
A VONTADE COMO PERFEIÇÃO PURA E A NOVA CONCEPÇÃO NÃO-EUDEMONÍSTICA DO AMOR SEGUNDO DUNS SCOTUS
}

Josef Seifert ${ }^{\star \star}$

SÍNTESE - Este estudo tem por objeto a filosofia scotista dos transcendentais, em especial a filosofia dos transcendentais como "perfeições puras". Isso levará a uma consideração particular da "liberdade" como uma perfeição pura, bem como à concepção de um novo conceito de amor, não presente no eudemonismo aristotélicotomístico.

PALAVRAS-CHAVE - Duns Scotus. Filosofia dos transcendentais. Perfeicõoes puras. Liberdade. Amor. Crítica ao eudemonismo.
ABSTRACT - The object of this study is Scotus's philosophy of the transcendentals, particularly the philosophy of the transcendentals as "pure perfections". That will bring into a special consideration of "freedom" as a pure perfection, as well as into the formulation of a new concept of love, not to be found in the Aristotelian-Thomistic eudaimonism.

KEY WORDS - Duns Scotus. Philosophy of the transcendentals. Pure perfections. Freedom. Love. Critique on eudaimonism.

\section{Introdução}

Duns Scotus, além de ter formulado de modo claro muitas idéias acerca da liberdade, afirmadas também por pensadores anteriores a ele, como a verdade necessária de que a vontade (racional) humana pressupõe o conhecimento, ${ }^{1}$ desenvolveu, segundo traços próprios, uma das mais originais filosofias da liberdade. ${ }^{2}$ Além da filosofia da vontade livre, a filosofia dos transcendentais de Scotus, tam-

\footnotetext{
Conferência proferida originalmente em espanhol, no X Congreso Latinoamericano de Filosofía Medieval, 19 a 22 de abril de 2005, na Pontificia Universidad Católica de Chile, em Santiago. No programa deste evento, o título dado à conferência foi "La voluntad como perfección pura y la nueva idea non-eudemonística del amor en Duns Scoto".

Università del Sacro Cuose/Milano.

Cf. Lectura II d. 25, q. un., n. 55. 68, p. 247. 252; Ordinatio IV d. 49, q. 9-10, n. 5, p. 189.

Isso é reconhecido por muitos autores. Cf., por exemplo, Walter HOERES, Der Wille als reine

Vollkommenheit nach Duns Scotus, 1962. Cf. também Richard CROSS, Duns Scotus, p. 57s. e William A. FRANK, Duns Scotus on autonomous freedom and divine co-causality, in: Medieval Philosophy and Theology, p. 153-6.
}

\begin{tabular}{|l|l|l|l|l|l|}
\hline VERITAS & Porto Alegre & v. 50 & n. 3 & Setembro 2005 & p. 51-84 \\
\hline
\end{tabular}


bém original e nova, particularmente a do "bonum", constitui uma outra parte revolucionária da sua doutrina metafísica. E essas duas teorias estão fortemente ligadas a um terceiro ensinamento de Scotus que consideraremos neste ensaio, a saber, que a liberdade é um "transcendental", no sentido de uma perfeição pura. Todos esses ensinamentos, por sua vez, dão ocasião a um conceito de amor radicalmente novo, como um ato autotranscendente que não pode ser explicado nas linhas do eudemonismo aristotélico-tomístico. Quanto a isso, Duns Scotus também pode ser considerado um precursor dos filósofos da resposta de valor e do personalismo do século 20, como Dietrich von Hildebrand e Karol Wojtyla. O propósito deste ensaio não é meramente estudar algumas das concepções de Scotus, mas sim as suas contribuições reais à "philosophia perennis", em direção a uma compreensão filosófica das coisas mesmas e da verdade acerca das coisas.

\section{A nova e original filosofia scotista das perfeições puras}

A proposição que se quer elucidar deve, de início, ser imediatamente apresentada: "Em poucas palavras, pois, pode-se dizer que uma perfeição pura é, absolutamente e sem qualificação, melhor do que qualquer coisa incompatível com ela". ${ }^{3}$

\subsection{A essência das perfeições puras}

Novamente, sugere-se aqui uma proposição breve:

A. A primeira e essencial característica das perfeições puras é esta: possuí-las é absolutamente melhor do que não possuí-las, seja por que razão for.

\subsubsection{A descoberta e a determinação fundamental das perfeições puras por Anselmo de Cantuária}

As "perfeições puras", cujo reconhecimento, ao menos implicitamente, ocupou um papel importante já na crítica do pré-socrático Xenófanes às concepções antropomórficas de Deus (ou dos deuses), características da religião grega, bem como na teologia filosófica de Platão e na teoria das idéias, ${ }^{4}$ perfeições essas que foram sempre pressupostas na metafísica e teologia clássicas, foram apreendidas pela primeira vez, com plena clareza filosófica, por Anselmo de Cantuária, na sua obra Monologion. ${ }^{5}$ Anselmo de Cantuária parte do problema de quais determina-

De primo principio c. 4, concl. 3.

Cf. a crítica de Platão ao antropomorfismo da religião grega, crítica esta inspirada em Xenófanes, em República II. Sobre as perfeições puras como o núcleo mais profundo das idéias platônicas, cf. o diálogo Fédon e ainda República VI-VII. Cf. também Josef SEIFERT, The idea of the Good as the sum-total of pure perfections. A new personalistic reading of Republic VI and VII, in: Giovanni REALE and Samuel SCOLNIKOV (eds.), New images of Plato. Dialogues on the idea of the Good, p. 407-424; idem, Ritornare a Platone. Im Anhang eine unveröffentlichte Schrift Adolf Reinachs, ed., preface and trans. by Giuseppe Girgenti. Collana Temi metafisici e problemi del pensiero antico. Studi e testi, Vol. 81, (Milano: Vita e Pensiero, 2000).

5 Monologion, cap. 15. 
ções do ser são características da natureza da essência divina. Ele chega à conclusão de que nenhum termo relativo, comparativo ou superlativo (tais como "melhor do que todos os outros entes" ou "o melhor de todos os entes") pode caracterizar adequadamente aquela natureza, mas que apenas "predicados absolutos" de substância, de ser (existência) ou de essência são característicos de tal ente absoluto. Anselmo considera as "perfeições puras", antes de mais nada, como um grupo de predicados absolutos (não-relativos).

Entretanto, para entender esse ponto, deveríamos distinguir, aqui, entre quatro sentidos radicalmente diferentes de "predicados absolutos":

(1) Primeiramente, estão incluídos sob esta fórmula aqueles predicados que podem pertencer a uma entidade "in se", isto é, não apenas em comparação com um outro ente. Nesse sentido, dizer de um homem que ele é bom seria uma predicação absoluta; dizer que ele é melhor do que um cachorro seria uma predicação relativa.

(2) Num segundo momento, predicados que são aplicáveis unicamente a uma certa natureza e delimitam uma essência de uma maneira não-ambígua seriam predicados absolutos. Nesse sentido, dizer de um homem que ele tem valor não seria uma predicação absoluta, enquanto dizer que ele é um animal racional o seria. ${ }^{6}$ Nesse segundo sentido, dizer que Deus é infinito em sua perfeição e que não possui nenhuma limitação, ou que ele é "id quo maius nihil cogitari possit", seria uma predicação absoluta, porque nada além de Deus tem essa característica. Tal predicação pode ser ou positiva, ou negativa, ou "relativa", no sentido de expressar uma relação que pertence apenas a um certo ente ou a uma certa natureza.

(3) Um terceiro sentido de predicados absolutos diria respeito àqueles que caracterizam uma coisa em si mesma ("in se") num outro sentido, que forma o contraste com aquilo que pertence a um ente, não apenas em comparação com, mas também relativo a uma outra coisa, tal como no caso em que a importância de um ente deriva apenas da sua relação com o nosso prazer ou também com a nossa felicidade e os nossos apetites. Nesse sentido, o valor objetivo ou o "bonum" intrínseco pertence a um ente "in se" - uma outra grande contribuição de Duns Scotus, à qual ainda retornarei -, enquanto o seu caráter como satisfazendo subjetivamente ou mesmo, em outro e mais objetivo sentido, como um bem objetivo para uma pessoa, ou como uma dádiva para nós, não seria uma predicação absoluta. Assim, dizer que Deus é infinitamente bom seria uma predicação absoluta; dizer que Ele é o bem maior para o ser humano seria uma predicação relativa.

(4) Dentro dos predicados absolutos dos tipos primeiro e segundo, Anselmo identifica um grupo único, as perfeições puras, e desse modo chega a um outro tipo (aqui, o quarto), dentre todos o mais importante sentido de "predicado abso-

\footnotetext{
Eu não discutirei, aqui, a questão se a definição de homem como um animal racional é adequada. Para uma crítica dessa definição e para a defesa de uma definição personalista do homem como uma "pessoa encarnada" ou como "uma pessoa que tem um corpo", cf. Josef SEIFERT, El hombre como persona en el cuerpo, in: Espíritu, p. 129-156.
} 
luto", a saber, as perfeições puras. Perfeições puras, então, são aquelas em relação às quais ser ou ter é absolutamente ("omnino") melhor ("melius simpliciter") do que não ser ou não ter, ou, como Duns Scotus mais tarde formularia, de modo mais agudo, possuir uma perfeição pura é melhor do que possuir qualquer propriedade com a qual uma perfeição pura é incompatível ("incompossibile"). Nesse quarto sentido, predicados absolutos são um outro termo para as perfeições puras, isto é, para aqueles atributos acerca dos quais possuir é absolutamente melhor do que não possuir e que não têm nenhum limite inerente.

Se o espírito humano pode na verdade conhecer propriedades absolutamente boas e perfeitas, em relação às quais ser ou ter é absolutamente melhor do que não ser ou não ter, por qualquer razão que seja, então nós estamos diante de uma das mais impressionantes capacidades do espírito humano, uma dimensão do conhecimento humano verdadeiramente capaz de fundamentar a metafísica. Se o ser humano pode, de fato, conhecer perfeições puras, então ele é capaz de apreender que, por exemplo, vida, sabedoria, conhecimento, ente, etc., tudo isso é absolutamente melhor ter do que não ter. Ele é então capaz de saber que é absolutamente impossível ser superior àqueles entes que possuem essas perfeições puras sem compreender essas mesmas perfeições numa maneira mais perfeita.

Anselmo faz uso da sua descoberta do caráter único das perfeições puras de uma maneira decisiva para a metafísica clássica e a filosofia da religião. Afinal, aquilo que não só é maior e melhor do que todos os outros entes, mas que é "aquilo acima do qual nada maior pode ser pensado", deve possuir todas as perfeições puras, em relação às quais ter (ou ser) é absolutamente melhor do que não ter ou não ser ("et quidquid similiter absolute melius est quam non ipse"): "vivo, sábio, poderoso e onipotente, verdadeiro, justo, santo, eterno", e todas as outras perfeições puras. Em contraste com isso, nenhum atributo que é essencialmente finito e limitado, tal como a natureza humana ou todas as naturezas dos animais e das plantas, pode ser predicado de um ente e de uma essência divina infinita.

Pode-se perceber, a modo de contraste, o significado desse conhecimento para a fundamentação da metafísica: imaginemos, por um momento, que o ser humano fosse capaz de conhecer exclusivamente o "misto", isto é, as perfeições e os atributos essencialmente limitados, que constituem o contrário das perfeições puras. Perfeições mistas ou "perfectiones secundum quid" são aquelas propriedades positivas que são essencialmente limitadas. A essas pertencem todas as naturezas e formas de ser próprias ao gênero e à espécie de entes finitos (anjos, seres humanos, animais, espécies animais individuais, plantas de toda espécie), deixando-se de lado, aqui, os assim chamados "gêneros primeiros", as categorias, algumas das quais são também perfeições puras.

Em adição aos diversos gêneros e às diversas espécies ontológicas, existem também inúmeras propriedades individuais, concretas e também gerais, tais como a posse de uma face bonita ou de músculos fortes, de agilidade e de rapidez na corrida, bem como outros valores vitais, que são "perfectiones limitatae". Se o 
nosso espírito fosse capaz de conhecer apenas tais perfeições essencialmente limitadas, então a metafísica, como uma ciência do ente como tal e como uma teologia natural puramente filosófica, seria completamente impossível. Mas, semelhantemente, seria impossível a revelação divina. O ente absoluto estaria escondido numa transcendência absolutamente incognoscível, tal que nós não poderíamos fazer, em absoluto, nenhuma reivindicação sobre o ente como tal ou sobre o ente absoluto, e tampouco poderíamos atribuir "ente" a Deus, muito menos perfeições puras pessoais como a onisciência. Toda teologia plena de conteúdo que predicasse qualquer atributo de Deus seria necessariamente antropomórfica, supersticiosa e falsa, uma idolatria de categorias essencialmente finitas. ${ }^{7}$ Ora, as perfeições puras são as condições do conhecimento de Deus, como nota Duns Scotus:

Com respeito a todas as coisas, à exceção das relações, tudo o que é incondicionalmente melhor do que algo que não é aquilo deve ser atribuído a Deus, mesmo porque tudo o que não é deste tipo deve ser negado dele. De acordo com Anselmo, então, nós primeiramente temos conhecimento de que algo é uma perfeição pura e, em segundo lugar, nós atribuímos essa perfeição a Deus. ${ }^{8}$

Existem muitas, possivelmente infinitamente muitas perfeições puras, embora nós normalmente falemos apenas de algumas poucas delas. ${ }^{9}$ Scotus aceita a lista inteira de perfeições puras dadas por Anselmo, no Monologion, quando escreve:

"[A substância da natureza suprema] não é, pois, um corpo", assim ele [Anselmo] o diz, "tampouco qualquer daquelas coisas que os sentidos corpóreos percebem... [Ela] deve ser vivente, sábia, onipotente, verdadeira, justa, eterna, e tudo aquilo que é, falando em sentido absoluto, melhor ser do que não ser". ${ }^{10}$

Contudo, como o próprio Anselmo o faz, Scotus adiciona muitas outras perfeições puras a essa lista, incluindo, por exemplo, a vontade livre.

\footnotetext{
Tal posição se encontra, num certo sentido, na teologia filosófica de Kant e de Jaspers, mas é observada, de outra maneira, também em Karl Rahner e Johann B. Metz. Josef Fuchs deriva conseqüências teológicas, morais e éticas radicais a partir dessa posição, a qual não podemos considerar aqui, mas que, contudo, tornam claro o peso concreto de nossos temas aparentemente abstratos e puramente metafísicos. Cf. Josef SEIFERT, Gott und die Sittlichkeit innerweltlichen Handelns. Kritische philosophische Reflexionen über den Einfluss anthropomorpher und agnostischer Gottesvorstellungen auf Ethik und Moraltheologie, in: Forum Katholische Theologie, p. 27-47. Também Jean-Luc MARION defende tal concepção na sua obra Dieu sans l'Etre, Paris, Communio/FAYARD, 1982, e em outros lugares. Para uma crítica dessa concepção, cf. Josef SEIFERT, Gott als Gottesbeweis. Eine phänomenologische Neubegründung des ontologischen Arguments, Heidelberg, Universitätsverlag C. Winter, 1996 (2. Aufl. 2000).

8 Cf. Ordinatio I d. 3, p. 1, q. 1-2, p. 24, n. 38. Cf. também Ordinatio I d. 2, p. 2, q. 1-4, p. 346-7, n. 382-84; Ordinatio I d. 8, p. 1, q. 1, p. 162, n. 22; Ordinatio I d. 8, p. 1, q. 4, p. 239-40, n. 167; Quodlibet 1, p. 12, n. 8; Quodlibet 5, p. 119, n. 13

9 Numa obra puramente filosófica, sobre os 99 (100) nomes de Allah, de acordo com o Islã, eu pretendo mostrar que a maioria deles ou todos eles são também perfeições puras e que o reconhecimento filosófico (e teológico) disso constitui um vínculo de comunhão verdadeiro entre o islamismo, o judaísmo e o cristianismo.

10 Quodlibet 1, p. 12, n. 8, citando Anselmo de Cantuária, Monologion cap. 15 (1: 28-29).
} 


\subsubsection{Dois refinamentos do pensamento de Anselmo, presentes na concepção filosófica de Scotus sobre as características essenciais primárias das perfeições puras}

Duns Scotus aprofundou a doutrina da primeira característica das perfeições puras, a qual exige um refinamento duplo, triplo até mesmo, como Scotus acuradamente observou. Como Allan B. Wolter mostrou de modo específico, ${ }^{11}$ Scotus aprofundou consideravelmente a doutrina das perfeições puras e tentou, com a ajuda das mais sutis construções conceituais, distinguir de modo mais claro as perfeições "puras" das perfeições "limitadas". Ele notou, antes de mais nada, que a essência das "perfectiones simpliciter" deve ser descrita de modo mais claro. A idéia "melhor ser do que não ser em qualquer coisa que as possui", melhor dito, "aquilo em relação ao que, em todo ente, é melhor que ele o seja do que ele não o seja", como Scotus resume a primeira caracterização anselmiana da essência das perfeições puras, requer, de acordo com Scotus, um refinamento duplo.

"Non ipsum" não deve ser entendido, aqui, meramente como um oposto contraditório simples (ausência, não-possessão), dado que também é válido para todas as perfeições limitadas que a sua simples não-possessão é menos perfeita do que a sua possessão. Por outro lado, é verdadeiro apenas das perfeições puras que toda forma de ausência dessas perfeições, num ente como tal, implica de si uma perfeição menor do que a sua presença, seja se essa ausência depende de um oposto contrário ou contraditório, de uma antítese negativa e privativa, ou de uma característica essencial positiva incompatível com a perfeição em questão ("quodcumque positivum incompossibile").

O segundo refinamento adicionado por Duns Scotus à distinção fundamental de Anselmo leva em consideração o próprio entendimento de Anselmo de que a não-possessão de uma perfeição pura pode ser preferível à sua possessão por razões acidentais, tal como o fato de que um ser humano bom e tolo é preferível a um ser humano sábio e mau. Isso, porém, não refuta a verdade de que a possessão da sabedoria e de outras perfeições puras é "per se" melhor do que a sua nãopossessão, seja por que razão for. ${ }^{12}$

O Doctor subtilis adiciona uma terceira percepção, a saber, que uma certa natureza, um cachorro, por exemplo, pode excluir a possessão de perfeições puras tais como a sabedoria, motivo pelo qual a sua possessão não seria boa para um indivíduo de tal natureza, porque, tornando-se sábio, o cachorro cessaria de ser um cachorro. Há naturezas que, por causa das suas limitações essenciais, não podem ser sujeitos de uma perfeição pura específica, e, com relação a elas, portanto, a possessão de uma perfeição pura não seria melhor do que a sua não-

1 Cf. Allan B. WOLTER, The transcendentals and their function in the metaphysics of Duns Scotus, St. Bonaventure/New York, Franciscan Institute Publications, 1946.

12 Cf. Monologion, cap. 15,27s., especialmente 31s.: "melius est sapiens quam non sapiens. Quamvis enim iustus non sapiens melior videatur quam non iustus sapiens, non tamen est melius simpliciter non sapiens quam sapiens. Omne quippe non sapiens simpliciter, inquantum non sapiens est, minus est quam sapiens". 
possessão, porque tal ente não teria a sua própria natureza, se ele tivesse aquela perfeição pura específica. ${ }^{13}$

Sendo este um ponto bastante forte, é filosoficamente menos convincente o argumento por meio do qual Duns Scotus substitui o possível "in cuilibet" com o "in quolibet" anselmiano. ${ }^{14}$ No intuito de expressar o seu terceiro ponto de maneira mais clara, Scotus distingue a expressão "in quolibet" ("em todo e qualquer ente"), na qual Anselmo viu que é melhor para algo possuir uma perfeição pura do que não possuí-la, da expressão "in cuilibet", significando esta um sujeito de uma determinada natureza. Portanto, o Doctor subtilis diz que a presença de uma perfeição pura é melhor do que a sua ausência para qualquer ente ou sujeito, abstratamente falando ("in quolibet"): "in quolibet habente ipsam melius est ipsam habere quam non ipsam habere" ("em todo e qualquer sujeito que a possui, é melhor possuí-la do que não possuí-la"), ${ }^{15}$ mas não para qualquer ente de uma dada natureza limitada ("in cuilibet"), um argumento e uma distinção que também são mantidos por Guilherme de Ockham. ${ }^{16}$ Embora brilhante a distinção, Duns Scotus parece, contudo, na sua interessante redefinição de perfeição pura por referência ao "in quolibet", separar natureza e sujeito de modo demasiadamente agudo, como ainda veremos. ${ }^{17}$

Naturalmente, isso não deveria excluir duas das percepções de Scotus que desenvolvem a descoberta de Anselmo: (a) que, até um certo ponto, um e o mesmo sujeito pode ser sujeito de diferentes naturezas, e que (b) pode muito bem ser o caso, portanto, para um dado sujeito de uma natureza específica, que seria melhor possuir uma perfeição (pura) que não é compatível com a sua natureza, mas sim com o fato de ser um dado sujeito que poderia ser submetido a alguma metamorfose na sua natureza. (Para um camundongo prestes a ser devorado por um gato, seria melhor ser um leão, caso em que ele não teria de estar com medo de ser devorado por um gato doméstico; num nível mais profundo, uma pessoa humana idêntica poderia ter recebido uma natureza angélica). ${ }^{18}$

${ }^{13}$ De primo principio, c. 4, concl. 3, p. 69: "Est, inquam, sic melius in quolibet - non cuilibet, sed in quolibet - quantum esset ex se". Cf. também Allan B. WOLTER, op. cit., p. 164s.; Quodlibet 5, n. 13. Cf. também John DUNS SCOTUS, A Treatise on God as First Principle (tradução de Allan B. Wolter), 4.10, disponível online: http://www.ewtn.com/library/THEOLOGY/GODASFIR.HTM.

14 Para uma discussão detalhada deste ponto, cf. Josef SEIFERT, Essere e persona. Verso una fondazione fenomenologica di una metafisica classica e personalistica, Capítulo 5.

15 Quodlibet 5, n. 13. Texto disponível online: http://www.ewtn.com/library/THEOLOGY/GODASFIR.HTM.

${ }^{16}$ Cf. Allan B. WOLTER, op. cit., p. 166, nota 12.

${ }_{17}$ De primo principio, c. 4, concl. 3, p. 69: "Est, inquam, sic melius in quolibet - non cuilibet, sed in quolibet - quantum esset ex se". Cf. também Allan B. WOLTER, op. cit., p. 164s. Eu tentei mostrar que a tese de que em qualquer sujeito a possessão de uma perfeição pura seria melhor do que a sua não-possessão é também indefensável, porque nenhum sujeito individual poderia ser sujeito de perfeições puras exclusivamente divinas, e porque há uma ligação mais profunda entre sujeito individual e natureza do que Scotus admite.

18 Eu não mantenho que isso realmente acontece, apesar de a doutrina de Orígenes defender que isso tenha acontecido, assim como toda a idéia ovidiana de certas "metamorfoses", o que ilustra a possibilidade e a justificação parcial da distinção de Scotus entre "in cuilibet" e "in quolibet". Como é bem conhecido, Orígenes, numa espécie de interpretação e antecipação metafísica radicalizada do 
Portanto, porque, por um lado, toda perfeição pura deve ser considerada absolutamente e comparada com toda forma possível da sua privação, para reconhecer a superioridade intrínseca garantida pela sua presença, e porque, por outro lado, uma perfeição pura (tal como a sabedoria) pode ser incompatível com uma natureza específica (por exemplo, a de um cachorro), Duns Scotus formula, com uma precisão justificadamente descrita por Walter Hoeres como "fenomenológica", a essência das perfeições puras do seguinte modo: "perfectio simpliciter est, quae est simpliciter et absolute melius quocumque incompossibili" "uma perfeição pura é aquela que é simples e absolutamente preferível a qualquer outra coisa ou propriedade que é incompatível com ela"). ${ }^{19}$

Esses refinamentos da percepção fundamental anselmiana sobre a essência das perfeições puras testemunham a sutileza e o espírito fenomenológico de Duns Scotus, qualidades que já têm sido notadas por muitos e que mereceram a Duns Scotus o título de "Doctor subtilis". É de fato incontestável que, para uma concepção precisa do caráter fundamental das perfeições puras, é decisivo reconhecer que, por um lado, toda forma de não-possessão de uma perfeição pura, mesmo pela razão de que uma natureza ou uma propriedade específica é incompatível com uma dada perfeição pura, implica uma perfeição menor do que a sua possessão, e que, por outro lado, existem de fato muitas naturezas que, por causa da sua estrutura essencial, são incompatíveis com certas perfeições puras. Com esses dois pontos decisivos, Duns Scotus clarificou de modo significativo a essência fundamental das perfeições puras.

\subsubsection{Desenvolvimento posterior e crítica de algumas teses de Duns Scotus sobre as perfeições puras}

Isso tudo leva a reconhecer a necessidade de um terceiro refinamento da descoberta de Anselmo, descoberta esta que toca o traço primeiro e mais fundamental das perfeições puras. Este traço está contido na "definição" das perfeições puras, proposta por Scotus.

Afinal, obviamente não há flexibilidade infinita na qual cada "suppositum" possa assumir qualquer natureza e perfeição: nenhum sujeito finito pode servir de ponte para o abismo entre a natureza finita e a infinita; também nenhum dado sujeito pode servir de ponte para o abismo entre a natureza pessoal e a não-

que seria expresso na Declaração de Independência dos Estados Unidos da América, defendeu que, originalmente, todas as pessoas criadas foram criadas iguais por Deus e que todas as pessoas humanas foram, originalmente, anjos. Cf. Origenes, in: The Ante-Nicene Fathers, Vol. 4, Origines, Book II, chap. VII, p. 285: "2. Now we are of opinion that every rational creature, without any distinction, receives a share of Him in the same way as of the Wisdom and of the Word of God". Cf. ibidem, chap. IX ("On the beginning of the worlds and its causes"), p. 291-2.

19 De primo principio, c. 4, concl. 3. Walter Hoeres acentua, corretamente, que Duns Scotus pratica, aqui, de maneira exemplar, a virada fenomenológica "de volta às coisas mesmas". Cf. Walter HOERES, op. cit., p. 17s.; idem, Critique of the transcendental metaphysics of knowing, phenomenology and neo-scholastic philosophy, in: Aletheia, p. 353-70; idem, Platonismus und Gegebenheit bei Duns Scotus, in: De Doctrina Ioannis Duns Scoti, Vol. I, p. 139-68. 
pessoal, no sentido de que uma substância idêntica de uma natureza finita jamais poderia adquirir atributos infinitos, ou que um dado sujeito não-pessoal jamais poderia, como o mesmo sujeito individual, assumir uma natureza pessoal. Existem limites definidos aqui, dos quais Scotus parece ter menos consciência do que Orígenes, o qual, apesar da sua idéia de que as pessoas humanas tinham primeiramente sido anjos, ensinou que uma transformação de entes não-pessoais em pessoas é absolutamente impossível. Caso se quisesse negar tais limites, um evolucionismo metafísico total a modo de Teilhard de Chardin se tornaria possível, na medida em que um supósito idêntico poderia assumir qualquer natureza e, portanto, adquirir qualquer perfeição pura criatural ou mesmo divina, mas isso é evidentemente absurdo. Por essa razão, é impossível aceitar o exemplo do cachorro, dado por Duns Scotus, em que para aquele, considerado como sujeito, seria melhor ser sábio do que não ser sábio. Pois, separado da sua natureza animal, ele cessaria de ser o mesmo sujeito idêntico.

Como resultado, a percepção essencial de Duns Scotus deve ser posteriormente diferenciada e formulada mais precisamente, da seguinte maneira. Nós podemos seguir, nisso, a definição do próprio Duns Scotus, uma definição que merece ser chamada de "clássica" e que está isenta dos pontos criticados: "uma perfeição pura é tal que ela é simples e absolutamente melhor do que toda e qualquer coisa que é incompatível [incompossível] com ela" ${ }^{20}$ Esta definição deixa em aberto se o "quocumque incompossibile" (o "todo e qualquer" que é incompatível com uma perfeição pura) é um sujeito ou uma natureza, ambos ou nenhum deles, como, por exemplo, "esse" ("ser"). ${ }^{21}$

A essência da perfeição pura também inclui alguma referência intrínseca à noção de "id quo maius nihil cogitari possit" ("aquilo acima do qual nada maior pode ser concebido"); como o "id quo maius nihil cogitari possit" deve possuir necessariamente todas as perfeições puras na sua plenitude maior, assim também cada perfeição pura é, na sua pureza, um "id quo maius nihil cogitari possit" ou parte dele.

\subsubsection{Mais acerca das perfeições puras e do conhecimento da sua "ratio formalis"}

Duns Scotus expõe de modo brilhante - mesmo que não possamos concordar com a sua interpretação desses conceitos e com a sua teoria do conhecimento das perfeições puras, concebida de modo demasiado formalístico, bem como com a

\footnotetext{
${ }^{20}$ Para uma caracterização essencial dos transcendentais e, em particular, da análise scotista extremamente original da vontade como perfeição pura, cf. também W. HOERES, Sein und Reflexion, p. 19s.; idem, Der Wille als reine Vollkommenheit nach Duns Scotus, p. 25s.

${ }^{21}$ Sobre isso, cf. também Josef SEIFERT, Sein und Wesen, in: Rocco BUTTIGLIONE und Josef SEIFERT (Hrsg.), Philosophie und realistische Phänomenologie/Philosophy and realist phenomenology. Studien der Internationalen Akademie für Philosophie im Fürstentum Liechtenstein/Studies of the International Academy of Philosophy in the Principality Liechtenstein, Heidelberg, Universitätsverlag C. Winter, Band 3, 1996.
} 
sua rejeição radical de qualquer agostinismo e platonismo - que o espírito humano pode abstrair precisamente essas perfeições puras de todas as limitações que acompanham a sua realização em entes finitos. Mais ainda, o conhecimento humano pode penetrar na forma essencial pura e única, na "ratio formalis", e mesmo no núcleo essencial da perfeição em questão, ${ }^{22}$ o qual, por um lado, constitui a essência formal que é a forma dessa perfeição e, por outro lado, é forma pura e livre das suas limitações acidentais em objetos finitos. No conhecimento da "ratio formalis" das perfeições puras, nós abstraímos, do objeto no qual é encontrada a perfeição que experimentamos, não uma "ratio formalis" em si mesma limitada e superável, como no caso do conhecimento das "perfectiones limitatae". Antes, o conhecimento da "ratio formalis" das perfeições puras, um conhecimento intuitivo e não-discursivo, que, de acordo com Duns Scotus, é o conhecimento mais elevado e científico, ${ }^{23}$ penetra na sua forma essencial correspondente em sua pureza, isto é, no ser em si mesmo, na vida em si mesma, no conhecimento em si mesmo, na liberdade em si mesma, etc. Na base dessas formas essenciais puras, é possível para o espírito humano ver que elas não são em si mesmas e necessariamente limitadas, e ver por que é da maior importância, para tanto, a idéia de que elas não podem ser superadas.

O entendimento humano é capaz, então, de distinguir entre essas perfeições puras em si mesmas e as suas limitações fáticas, em todas as formas nas quais elas se apresentam, dentro dos objetos da nossa experiência. O ser humano é capaz, no seu conhecimento, de proceder até àquele ponto no qual a "impossibilidade de ultrapassá-las sem possuí-las", como pode também ser chamada a característica essencial fundamental primária das perfeições puras, revela a si mesma ao espírito. Isso poderia mesmo ser uma outra definição da primeira característica fundamental e essencial das perfeições puras. É impossível ultrapassar "o ente" ["das Seiende"], sem ser, ultrapassar a existência, sem existir, ultrapassar o bom e valoroso em si mesmo, sem ser em si mesmo bom e valoroso. É semelhantemente impossível ultrapassar a pessoa, sem ser pessoal, ultrapassar o absolutamente infinito e eterno, sem possuir essas mesmas perfeições puras.

\subsubsection{O problema do conhecimento das perfeições puras e a epistemolo- gia scotista das perfeições puras - exposição e comentários críticos}

Como deveríamos entender o conhecimento das perfeições puras? Na sua teoria do conhecimento das perfeições puras, Duns Scotus é muito mais radicalmente aristotélico do que Tomás de Aquino, que - sobretudo em De Veritate permanece muito mais próximo de Agostinho do que de Aristóteles, na questão específica do conhecimento das perfeições puras. Duns Scotus nega, na sua inter-

${ }^{22}$ Acerca desta noção, introduzida por Jean Hering, cf. Josef SEIFERT, Essence and existence, in: Aletheia, p. 17-157; idem, Sein und Wesen, Capítulo 1.

${ }^{23}$ Sobre isso, cf. a interessante dissertação de Roberto Hofmeister PICH, Der Begriff der wissenschaftlichen Erkenntnis nach Johannes Duns Scotus, 2001, p. 30s., em que se prova que Duns Scotus defende um certo ideal de ciência que é, em primeiro lugar, conhecimento intuitivo. 
pretação da teoria aristotélica do conhecimento, qualquer conhecimento de uma forma ou perfeição essencial, de um "conceptus proprius" do "primum analogatum" da perfeição pura. Duns Scotus assevera, ademais, que o nosso conhecimento das perfeições puras começa exclusivamente na apreensão da "ratio formalis" delas e procede, a partir disso, num processo intelectual imanente, isto é, sem qualquer percepção e sem qualquer contato cognitivo com uma forma que é eterna, pura, ou superior aos objetos da experiência. De acordo com Duns Scotus, o espírito humano simplesmente remove da "ratio formalis", a qual ele abstrai da perfeição experimentada, as limitações que ela tem nos objetos experimentados, e então atribui a "ratio formalis" a Deus "da maneira mais perfeita possível" ("perfectissime"). Dessa maneira, Duns Scotus procura reduzir o processo do conhecimento das perfeições puras a um processo imanente das formas essenciais das coisas que são dadas nas "imagens sensíveis" ("phantasmata").

Nós não podemos entrar, aqui, numa crítica detalhada dessa epistemologia scotista das perfeições puras, mas poderíamos, sim, perguntar: ${ }^{24}$ como pode o espírito humano, conforme acentua Duns Scotus, reconhecer na "ratio formalis" da justiça que ela é uma perfeição pura, se a mente humana não entende verdadeiramente, na forma essencial pura de justiça, mesmo se apenas imperfeitamente, a sua profundidade ilimitada e a sua forma puramente perfeita?

As análises sutis das perfeições puras, feitas por Scotus, permanecem sendo, entretanto, apesar de exigir refinamentos posteriores, a contribuição historicamente mais significativa para uma fenomenologia das perfeições puras. ${ }^{25}$ A profundidade com a qual Scotus apreende a natureza necessária e inteligível das perfeições puras se torna particularmente clara, quando nos voltamos a um outro desenvolvimento significativo por meio do qual Scotus clarifica a natureza das "perfeições puras". Trata-se da distinção de cinco características essenciais das perfeições puras, que são distinguidas da estrutura essencial fundamental, o primeiro momento essencial das perfeições puras, muito embora estejam enraizadas nessa mesma estrutura. Todas essas características essenciais posteriores das perfeições puras estão necessariamente ligadas à sua natureza fundamental, mas podem, contudo, ser elaboradas como momentos distintos.

\subsection{A compatibilidade mútua das perfeições puras}

Considere-se a seguinte proposição:

B. Todas as perfeições puras são mutuamente compatíveis - "Nulla perfectio simpliciter est incompossibilis alteri perfectioni simpliciter".

24 Sobre isso, cf. Josef SEIFERT, Essere e persona, Capítulo 5.

Cf., em particular, Quodlibet 5. Cf. também Efrem BETTONI, Duns Scotus: the basic principles of his philosophy, Washington (D.C.), The Catholic University of America Press, 1961. A dimensão fenomenológica da teoria scotista das perfeições puras é trabalhada com grande penetração por Walter HOERES, Der Wille als reine Vollkommenheit nach Duns Scotus, p. 17s. 149s. A "volta às coisas mesmas" se mostra de modo particularmente impressionante na análise de Scotus da vontade e do amor, que depende da noção de "affectio iustitiae". 
A tese - de que nenhuma perfeição pura pode ser incompatível com uma outra - é primeiramente fundamentada por Duns Scotus na definição das perfeições puras, de maneira aparentemente tautológica. Se alguém interpreta a "ratio" (a definição, a essência) das perfeições puras como "ipsa est melior in quolibet... quam quodlibet incompossibile sui" ${ }^{26}$ e se existem, então, duas perfeições puras, $A$ e $B$, que se excluem mutuamente, então dois estados de coisas mutuamente opostos de modo contraditório podem ser derivados a partir dessas duas premissas. Pois, na base dessa acepção, a possessão de uma e a mesma perfeição $A$ seria, ao mesmo tempo, menos perfeita do que a sua não-possessão (na base da aplicação da definição das perfeições puras à perfeição $B$ e da sua incompatibilidade com a perfeição $A$ ), e também mais perfeita do que a sua não-possessão (na base da aplicação da mesma definição das perfeições puras à perfeição $A$ ela mesma). Duns Scotus, portanto, nos chama a atenção para uma contradição lógica entre a acepção da incompatibilidade de qualquer perfeição pura com qualquer outra e a definição da essência das perfeições puras como tais.

Entendendo-se assim esse argumento lógico-formal de Scotus, isto é, que simplesmente contradiz à definição das perfeições puras que duas diferentes perfeições puras se excluam mutuamente, então nada está provado sobre as coisas mesmas. Tudo o que Duns Scotus mostraria, então, seria a verdade de um juízo analítico, isto é, que uma definição específica das perfeições puras implica "per definitionem" que nenhuma perfeição pura pode ser incompatível com uma outra. Ainda nenhuma asserção sobre a realidade se segue, a partir desse juízo analítico, pois seria o caso, então, de a definição das perfeições puras ser aplicável a perfeições concretas apenas nos casos em que essas perfeições não se contradizem mutuamente. A demonstração de uma contraditoriedade puramente lógica entre essas duas teses arbitrariamente assumidas sobre as perfeições, ou melhor, da implicação lógica, em virtude da qual a definição das perfeições puras acarreta a sua compatibilidade, seria naturalmente de pouco significado ou de nenhum significado para a metafísica.

O que Duns Scotus de fato deseja mostrar, entretanto, é algo muito mais profundo. A sua prova apresenta uma demonstração metafísica profundamente válida para a segunda característica das perfeições puras, se essa demonstração não procede de uma definição arbitrária das perfeições puras, mas, antes, da sua natureza objetiva e, em particular, da primeira característica fundamental de toda perfeição pura. Se as premissas do argumento scotista, isto é, se a definição das perfeições puras como nós a formulamos acima - às vezes, em distância crítica para com Duns Scotus - não é proposta de modo meramente arbitrário, mas é obtida na base da natureza da "coisa-perfeição pura" em si mesma, então a prova scotista para a compatibilidade necessária de todas as perfeições puras umas com as outras é profundamente válida e bem formulada, porque tanto válida na sua forma lógica quanto fundada em premissas verdadeiras e evidentes. ${ }^{27}$

Quodlibet 5, n. 8.

Ibidem. 
O argumento para a unidade interna de todas as perfeições puras depende, portanto, na sua validade e na sua verdade metafísica, e na sua capacidade de provar a unidade de todas as perfeições puras, do conhecimento do fato de que nós apreendemos o caráter absoluto próprio das perfeições puras como algo que não está atribuído de forma alguma de modo arbitrário a elas, na base de uma definição arbitrária subjetiva, mas que é encontrado nelas como parte da sua essência objetiva. Precisamente, apenas se o caráter do ente e das outras perfeições puras como absolutamente insuperáveis é dado a nós, apenas se nós apreendemos a perfeição insuperável real das "perfectiones simpliciter", o argumento scotista para a unidade interna das perfeições puras possuirá uma validade estrita, não baseada na mera definição, mas na essência objetiva das perfeições puras.

Não apenas o destino da prova scotista para a compatibilidade de todas as perfeições puras, mas também o destino da metafísica mesma depende do conhecimento de que existem perfeições puras. Se tal conhecimento é impossível, então a metafísica, como o conhecimento do ente na sua totalidade e, de modo mais compreensivo, do ente absoluto, é também "eo ipso" impossível. Nesse caso, o argumento scotista para a unidade de todas as perfeições puras se transformaria numa mera tautologia, que deduz de uma definição arbitrária algo que reside implicitamente dentro dela. Caso, porém, se torne evidente que o que nós procuramos provar é de fato o caso, isto é, que do dado das "perfectiones simpliciter" mesmas pode ser visto que a sua possessão é absolutamente melhor do que a sua não-possessão, então se segue dessa característica fundamental, e é de fato dado conjuntamente com a percepção fundamental do caráter de uma perfeição pura como tal - ao menos implicitamente -, que também todas as perfeições puras são mutuamente compatíveis. A prova scotista, então, mostra que, com necessidade lógica e metafísica estritas, toda perfeição, que de fato possui a essência da perfeição pura (ser absolutamente melhor do que alguma coisa que não a possui ou é incompatível com ela), deve ser compatível com toda outra perfeição, e que, portanto, todas as perfeições puras poderiam ser simultaneamente possuídas e realizadas.

Para que, pois, seja convincente, o argumento scotista deve ser concebido de forma que aponte para a contradição essencial que reside na concepção do caráter fundamental da perfeição pura e de qualquer incompatibilidade mútua entre as perfeições puras. Se pode ser mostrado que é uma característica objetiva de toda "perfectio simpliciter" que possuí-la é melhor do que não possuí-la (como no caso de todo e qualquer ente ou de toda e qualquer natureza que não a possui ou não pode possuí-la), então o argumento de Duns Scotus, introduzido acima, para a compatibilidade mútua de todas as perfeições puras, repousa numa base objetiva e metafísica, e procede, não a partir de uma mera definição arbitrária, mas de um axioma objetivo, isto é, de uma lei essencial das coisas mesmas.

Esse ponto de partida autenticamente metafísico para o argumento scotista foi encontrado e demonstrado por meio de uma contemplação mais profunda da essência das perfeições puras. Nós entendemos, portanto, que a "ratio formalis", a "essência mesma" de uma perfeição pura, é de tal tipo que é impossível que a 
perfeição pura possa ser ultrapassada em perfeição por qualquer coisa que a exclui ou é "incompatível" ("incompossibile") com ela. À medida que a primeira característica fundamental das perfeições puras foi mostrada estar fundamentada nas coisas mesmas, é também impossível disputar a fundamentação objetiva do argumento a favor da compatibilidade mútua e da "unificabilidade" de todas as perfeições puras.

O ponto que está em questão, aqui, é, porém, muito mais profundo do que a "compossibilitas" na qual Duns Scotus insiste. Ele diz respeito, a saber, não somente à compatibilidade, mas a uma união interna muito mais elevada de todas as perfeições puras, de modo que nenhuma delas pode ser plenamente ela mesma sem todas as outras. É evidente, por exemplo, que a plenitude da perfeição do ente é absolutamente inseparável daquela da vida e da bondade. Por essa razão, Tomás de Aquino insiste, freqüentemente, na unidade interna perfeita de todas as perfeições em Deus: "in creaturis quae quidem perfectiones in deo praeexistunt unite". ${ }^{28}$

\subsection{Um refinamento à contribuição de Scotus sobre as perfeições puras}

Agora, cabe analisar o seguinte enunciado:

C. Toda perfeição pura admite a infinitude. Ou: uma perfeição pura é ela mesma plenamente apenas quando ela é infinita.

As percepções essenciais que nós obtivemos até este ponto nos permitem proceder para além das mesmas, para um conhecimento mais profundo das perfeições puras. Em princípio, poderia ser o caso que ninguém é, de fato, capaz de ultrapassar a sabedoria, sem ser sábio, etc., e também que todas as perfeições puras podem ser simultaneamente possuídas, mas que, entretanto, todos os entes poderiam possuir, por natureza, essas perfeições puras apenas numa medida finita, e que, em realidade, não existe nenhum ente infinito.

Essa opinião é encontrada, por exemplo, na defesa de Charles Hartshorne, de acordo com a filosofia do processo, do argumento ontológico a favor da existência de Deus. Hartshorne mantém a posição de que a perfeição de Deus é absolutamente "insuperável" em relação a qualquer outro ente, mas ela poderia superar a si mesma, e, portanto, não é atualmente infinita. De modo semelhante, não se segue imediatamente ou com conseqüência lógica do nosso conhecimento até este ponto que a infinitude mesma é uma perfeição pura, tema sobre o qual Aristóteles, por exemplo, disputa. ${ }^{29}$

${ }^{28}$ Summae theologiae I q. 1, 3, a. 4; In I Sententiarum d. 2, q. 1, a. 3: "quia in deo sunt omnes perfectiones adunatae...". Cf. ainda Summae theologiae I q. 1, 3, a. 5: "perfectiones, quae sunt in rebus creatis divisim et multipliciter".

29 Cf. ARISTOTLE, Physics III, 6; VI, 6. Sobre a história da filosofia da infinitude e sobre a sua introdução tardia na teologia e no ensino da Igreja, cf. Leo SWEENEY, Divine infinity in Greek and Medieval thought, New York/San Francisco/Bern/Frankfurt a.M./Berlin/Wien/Paris, Peter Lang, 1992. 
É necessário, portanto, demonstrar os seguintes três fatos, no intuito de estabelecer a possibilidade da infinitude atual de toda perfeição pura: que a infinitude absoluta como tal é uma perfeição; que a infinitude é uma perfeição pura; que, portanto, nada finito pode ultrapassar o infinito em perfeição. A partir desses três fatos, em particular a partir do caráter de perfeição pura da própria infinitude absoluta, segue-se claramente que toda perfeição pura é compatível com a infinitude absoluta. De outro modo, a perfeição pura "infinitude" contradiria outras perfeições puras, o que entra em conflito com a segunda característica essencial das perfeições puras.

\subsubsection{Infinitude absoluta como perfeição pura}

No intuito de entender que a infinitude absoluta é uma perfeição pura, é necessário, primeiramente, entender a natureza essencial da infinitude absoluta e delimitá-la de outras "infinitudes finitas".

Há, primeiramente, uma infinitude dentro de entes finitos, a infinitude dentro de uma parte limitada ou de um aspecto limitado do ser, por exemplo, a infinitude de seqüências naturais e de outras seqüências numéricas, de espaço ou de tempo; ou também a infinitude da divisibilidade de todo espaço ou intervalo de tempo. Tal "infinitude dentro do finito" aparece em entes ou em fenômenos que pressupõem tempo, espaço ou a sua divisibilidade infinita, fenômenos tais como o movimento, por exemplo. ${ }^{30}$

Algumas dessas infinitudes dentro do finito, por exemplo aquelas do espaço e do tempo, pressupõem a extensão, enquanto outras, em contraste, não a pressupõem (como, por exemplo, a infinitude das seqüências de números naturais). Nós podemos fazer, ordenadamente, alguns comentários sobre todas as formas do "infinito dentro do finito".

Primeiro, o infinito é incomensurável com qualquer distância finita ou com qualquer divisão finita, seja número, divisibilidade, etc. Em segundo lugar, o infinito dentro do finito contém, contudo, dentro de si mesmo, partes finitas (embora ele jamais possa ser medido por essas partes e seja sempre mais amplo do que um todo que consiste dessas partes, porque nenhuma adição de partes finitas pode jamais somar à infinitude). Por semelhante modo, o infinitamente pequeno é também menor do que qualquer parte menor, porque tal parte pode sempre ser novamente dividida. Por exemplo, existem, numa linha infinita, infinitamente muitos trechos. Esses trechos finitos são realmente partes da linha infinita.

Em terceiro lugar, o infinito dentro do finito tem características totalmente diferentes daquelas que as partes finitas dessa infinitude possuem. Essas características do infinito parecem apresentar um paradoxo. Pensemos, por exemplo, no fato de que, se um número infinito é dividido por um outro número, ele permanece, contudo, infinito, ou pensemos no fato de que o número infinito não pode nem ser

${ }^{30}$ Cf. Adolf REINACH, Über das Wesen der Bewegung, preparado para publicação por Edith Stein, com base em notas de seminário, in: Adolf REINACH, Gesammelte Schriften, p. 406-61. 
par nem ser ímpar, muito embora isso pareça ser da essência dos números naturais. Isso aponta, novamente, para a transcendência e para a incomensurabilidade da infinitude em relação a qualquer coisa finita, e aos profundos enigmas e às aporias escondidas nela. ${ }^{31}$ Em quarto lugar, finalmente, essas infinitudes, dentro de uma esfera finita do ser, são, contudo, limitadas e finitas no sentido de que estão restritas a uma esfera limitada do ser: números, tempo, espaço, linhas, etc. O conteúdo que é o sujeito dessas infinitudes é profundamente contingente, isto é, é limitado e claramente subordinado a outras realidades que figuram mais elevadas do que ele em valor, tais como a pessoa, por exemplo.

Completamente diferente desse tipo de infinitude é aquela infinitude que podemos caracterizar como infinitude absoluta. O absolutamente infinito é, antes de mais nada, num sentido essencialmente mais profundo e diferente do que o infinito dentro do finito, absolutamente incomensurável com qualquer finito. Essa transcendência absoluta em relação a todas as realidades finitas fica mais clara, quando pensamos numa segunda característica essencial da infinitude absoluta. 0 absolutamente infinito não contém, de maneira nenhuma, momentos finitos como partes reais ou elementos atuais de si mesmo. O absolutamente infinito não consiste de trechos ou elementos finitos, no sentido no qual estes são partes do infinito dentro do finito.

Em terceiro lugar, e de significado ainda maior, menciona-se a idéia de que o absolutamente infinito de modo nenhum está dentro de uma esfera essencialmente limitada ou aparece como um aspecto essencialmente limitado dos entes. O seu sujeito é ele mesmo infinito, e é infinito em todos os aspectos. Em quarto lugar, o sujeito da infinitude absoluta inclui todas as perfeições puras, em relação às quais é absolutamente melhor ter ou ser do que não ter ou não ser. O contrário exato vale do infinito dentro do finito, onde é mais perfeito estar além da esfera total do ente ao qual essas infinitudes são próprias: números, espaço, tempo, linhas, etc. Em quinto lugar, o absolutamente infinito é caracterizado primariamente pelo seu núcleo essencial, a saber, pela infinitude da sua perfeição. Ela somente pode ser caracterizada, nas palavras de Anselmo, como "aquilo acima do qual nada pode ser maior", ou "aquilo acima do qual nada maior pode ser (sequer) pensado". Essas formulações, com as quais Scotus, em seguimento a Anselmo, procurou caracterizar a essência do infinito absolutamente, se referem direta e exclusivamente ao infinito absolutamente (Deus).

\subsubsection{Perfeições puras como a chave indispensável para o entendimento da infinitude absoluta}

As perfeições puras oferecem um acesso único à infinitude absoluta, de fato, o único acesso possível. Pois, se nós apreendemos a natureza fundamental de uma perfeição pura em absoluto, a saber, que ela não é simplesmente "per definitionem", mas "per essentiam" melhor do que qualquer coisa que é incompatível com

Cf. Bernard BOLZANO, Paradoxien des Unendlichen, Hamburg, Felix Meiner Verlag, 1975. 
ela, nós deveríamos estar imediatamente conscientes de que essa percepção não poderia ter sido alcançada por uma ascensão gradual, a partir do limitado até ao mais perfeito, numa série finita de passos - mesmo se também infinitamente estendida.

Portanto, apenas porque na apreensão da perfeição pura como "perfectio simpliciter" a sua infinitude absoluta potencial é compreendida simultaneamente é que é possível reconhecermos, em absoluto, uma perfeição pura como pura. Mas, por isso mesmo, a "perfeição pura" da infinitude absoluta é também dada conjuntamente. E, assim, nós entendemos também, na base da segunda característica essencial das perfeições puras, que toda perfeição pura deve necessariamente ser compatível com a infinitude absoluta, de modo que podemos, com Duns Scotus, oferecer uma "definição essencial" adicional das perfeições puras: "uma perfeição pura é aquela perfeição que é capaz de ser formalmente infinita" ${ }^{32}$

A "ratio formalis" de que a forma essencial pura de uma perfeição pode ela mesma ser "formalmente infinita" significa que não existe, e não poderia existir, uma outra perfeição mais elevada que contém aquela forma mais baixa numa maneira eminente (como é o caso com as "perfectiones limitatae"), mas sim que "esta perfeição ela mesma", na sua "simplicitas" e na sua identidade irredutível, na sua própria "ratio formalis" como tal, pode ser infinita. Nesse ponto, nós precisamos dar, contudo, um passo posterior, que Duns Scotus não dá explicitamente e que, de fato, na base da sua rejeição radical de toda epistemologia agostinianoplatônica, ele não teria sido capaz de justificar.

\subsubsection{Uma perfeição pura é "ela mesma" apenas na sua forma infinita}

A mais penetrante percepção da essência das perfeições puras consiste no fato de encontrarmos nelas o dado de que elas não possuem meramente ser infinito, perfeito, e meramente admitem a infinitude, mas que elas são em si mesmas primariamente na sua forma infinita. O que constitui a sua essência atual não é dado a nós primariamente nas suas realizações finitas, mesmo se estas nos oferecem o nosso acesso experimental ao conhecimento das perfeições puras. Seja o quanto possa ser verdadeiro que as perfeições puras são experimentalmente acessíveis exclusivamente nas suas formas finitas, e podem ser conhecidas apenas através do espelho do mundo, nós, entretanto, chegamos ao mesmo tempo a conhecer que toda perfeição pura é primeiramente "ela mesma" na sua forma perfeita, infinita. Em outras palavras, é evidentemente dado que, no caso das perfeições puras, o "primum analogatum" é a forma autêntica na qual apenas a "forma et ratio formalis" de uma perfeição pura é completamente "ela mesma". O conhecimento fascinante que nós obtemos aqui é o conhecimento de que a "ratio formalis" das perfeições puras contradiz claramente todas aquelas limitações nas quais essas perfeições puras são experimentalmente acessivieis a nós. A vida da qual sabemos e

${ }^{32}$ Ordinatio I d. 8, q. 2, n. 3: "Solum illud est perfectio simpliciter quod potest esse in aliquo infinitum". 
temos experiência não é de fato "a vida mesma", a justiça que experimentamos neste mundo não é "a justiça mesma", a autopossessão substancial das coisas no mundo também não é "a substância mesma", a pessoa finita não é a encarnação mais autêntica do ser pessoal. A limitação contradiz o "logos" pleno e a "ratio" plena dessas perfeições.

Precisamente porque apreendemos essas perfeições, reside no nosso conhecimento de uma perfeição pura uma transcendência única. Essa transcendência está claramente presente em todo conhecimento de uma perfeição pura como tal. $\mathrm{E}$ é primariamente nesse conhecimento transcendente que fundamentamos o estado de coisas que Scotus mesmo formulou, a saber, que devemos predicar como a "ratio formalis" das perfeições puras o ente absolutamente perfeito, o "perfectissimum".

Isso não deveria ser tomado como uma negação de que a "ratio formalis" está de fato verdadeiramente presente no ente finito, ou de que ela é abstraída dele, isto é, que ela pode ser reconhecida com base no nosso contato com o ente finito. Ainda, a essência formal de uma perfeição pura está apenas presente numa maneira infinitamente fraca em entes finitos, numa maneira que reconhecemos não ser a perfeição pura "in se". Portanto, qualquer tipo de inferência ao mais elevado (à encarnação perfeita de uma "perfectio simpliciter"), a partir do mais baixo (a saber, a partir da realização de uma perfeição pura num objeto finito), é impossível. Afinal, uma perfeição pura vem a ser conhecida apenas na medida em que ela nos permite, na base da sua essência atual, obter uma percepção da sua "forma" infinita, na qual apenas ela é "ela mesma" (por exemplo, a própria justiça). Apenas quando apreendemos isso, apenas quando a encarnação finita de uma perfeição pura se torna transparente ao fato de que essa perfeição pode ser o que ela é, na sua autenticidade, apenas na sua forma infinita, podemos conhecer uma perfeição pura como tal.

Somente agora encontramos a explanação para certas idéias fascinantes de Scotus acerca do modo infinito, em contraste com o modo finito do ser das perfeições puras. Scotus coloca a si mesmo a questão de como se dá o fato de que atos e qualidades (tais como conhecer, querer, amar) seriam perfeições puras, uma vez que eles parecem ser essencialmente acidentes, e, em comparação com a substância, possuem um modo imperfeito de ser. Scotus responde à questão com a distinção entre as perfeições puras "como princípio aperfeiçoador" - e, nesse sentido, elas podem ser absolutamente perfeitas - e "como acidente" (isto é, como "um princípio diferente da habilidade de amar ou do ato de amor"), que é uma forma imperfeita de realização de uma perfeição pura, e que, portanto, não pertence à sua natureza como uma perfeição pura. ${ }^{33}$ Uma distinção semelhante já se encontra na Summa theologiae de Tomás de Aquino.

Duns Scotus não nota esse fato explicitamente, muito provavelmente por causa da sua posição que rejeita todo conceito análogo de ente, isto é, exclui que possamos apreender o primeiro analogato em absoluto - isto é, as perfeições puras na sua forma infinita específica. Essa acepção tem a sua raiz na dura crítica de Duns Scotus ao agostinismo de Henrique de Gand. Nós não queremos entrar 
Mas, como é possível saber disso sem um certo conhecimento positivo do arquétipo das perfeições puras (do seu "primum analogatum")? No modo de infinitude, toda perfeição pura deve ser "sabedoria pura subsistente-em-si-mesma, bondade, etc.". Como nós podemos saber disso, por meio da abstração, a partir das formas finitas, as quais estão contidas nos "phantasmata" e nas quais as "perfectiones simpliciter" estão realizadas apenas imperfeitamente, e jamais subsistentes e puras?

Scotus chega ainda a uma outra idéia de grande importância, que foi considerada detalhadamente por Hoeres. ${ }^{34}$ Embora as perfeições puras excluam toda imperfeição, há, contudo, uma ordenação e uma relação hierárquica entre elas. Assim, por exemplo, a vida é mais elevada que a existência simples, o amor é mais elevado que a vida. Mas, como isso pode ser o caso, se, de fato, toda perfeição pura é infinita e insuperável? Scotus responde que tal hierarquia poderia ser verdadeira das perfeições puras, apenas se elas fossem tomadas em abstração completa, a partir dos seus modos, ou se elas fossem consideradas nas suas atualizações criaturais limitadas. No "modo de infinitude", elas são todas igualmente perfeitas, porque são infinitas. ${ }^{35} \mathrm{Na}$ sua forma infinita, toda perfeição - apesar da preservação de uma distinção formal entre elas - é una com toda outra, e por isso mesmo a hierarquia entre elas é superada. Ente infinito é infinito amor, apenas amor infinito pode também ser vida infinita, etc. Tal conhecimento, entretanto, é também impossível de obter-se com base na abstração, a partir das formas apresentadas nas imagens sensíveis. ${ }^{36}$

Um tomista poderia objetar que nós introduzimos, neste ponto, uma visão direta de Deus, tal como o ontologismo assume, ou mesmo, possivelmente baseado no ensino scotista dos conceitos unívocos de ente e de todas as perfeições puras, uma univocidade daqueles conceitos que se referem às encarnações finitas das perfeições puras e daqueles que se referem à sua realização infinita. Parecemos, a partir disso, negar o fato, corretamente enfatizado por Tomás de Aquino, e mais tarde declarado dogma da Igreja Católica, de que a diferença entre o "exemplar" e o "exemplatum", entre Deus e qualquer criatura, é sempre maior do que a sua semelhança.

Tais conseqüências, entretanto, de modo algum resultam de nossas reivindicações. A distância infinita entre a encarnação arquetípica de uma perfeição pura e a participação finita nela não está de modo algum eliminada. Entretanto, desejamos afirmar, sim, que a distância infinita entre a realização perfeita-infinita da "perfectio simpliciter" e a sua realização finita não está fundada no fato de que o

nessa controvérsia histórica. Naturalmente, Scotus não nega que todas as perfeições puras estão primariamente em Deus. Sobre isso, cf. também W. HOERES, Der Wille als reine Vollkommenheit nach Duns Scotus, p. 61s.

Ibidem, p. 51.

5 Ibidem, p. 61s., em especial p. 65s.

${ }^{36}$ De fato, conhecimento e amor finitos, na medida em que são atos espirituais, não são formas das imagens sensíveis, para não falar daquilo que pertence exclusivamente à realização infinita de uma perfeição pura. 
modo infinito de ser ou o conhecimento de qualquer perfeição pura é completamente diferente do finito, no sentido de que elas são "outra coisa que o ser ou o conhecimento" - assim como é o caso, em todos os exemplos, com as "perfectiones limitatae" -, mas, ao contrário, no fato de que o infinito apenas é plenamente o que nós entendemos que o ser ou o conhecimento são. E a profundidade misteriosa e inescrutável do ente divino e a sua incompreensibilidade estão precisamente fundadas neste ser, no sentido mais verdadeiro, e neste conhecer, no sentido mais verdadeiro, bem como na possessão mais verdadeira e mais plena de todas as perfeições puras. Ele apenas é, ele apenas tem conhecimento, ele apenas é bom, etc. A distância infinita está fundada no modo no qual o ente infinito apenas possui, em plenitude transcendente, aquelas "rationes formales" que nós encontramos em entes finitos apenas num modo radicalmente fraco. No caso das perfeições puras, o ente infinito não possui perfeições diferentes, mas antes as mesmas perfeições, embora de modo completamente diferente, a saber, de modo ilimitado e verdadeiro, e em unidade última, de modo que esse ente é verdadeiramente o próprio ente, o próprio bem, a própria sabedoria, a própria liberdade, etc.

Com essa asserção, também não postulamos nenhuma visão direta, natural, de Deus, mas, antes, apenas sugerimos que a verdadeira natureza infinita de toda perfeição pura - o quão imperfeitamente acessível ela seja ao espírito humano está sempre dada conjuntamente, toda vez que chegamos a conhecer uma perfeição pura como tal. E, nesse sentido, podemos dizer, com Agostinho, que alguém que contempla o bem, não este ou aquele bem limitado, mas o bem em si mesmo, "vê a Deus".

Nós veremos, mais tarde, que existem perfeições puras (tais como eternidade, infinitude absoluta, existência real necessária) que podem subsistir exclusivamente num ente absoluto, divino. Aquelas perfeições puras, entretanto, que existem também nos entes finitos, permitem uma relação particular entre o ente finito e o ente infinito. Elas também permitem, em última instância, aquela relação significativa e extremamente diferente que as "perfectiones limitatae" têm com o ente infinito dentro da "analogia entis". Nós não podemos, entretanto, entrar nessa discussão em mais detalhes.

O ponto decisivo na nossa discussão permanece sendo que toda perfeição pura, se nós penetramos na sua essência formal, isto é, se nós entendemos precisamente aquilo que a constitui como esta perfeição particular, é acessivel a nós pela experiência apenas na sua realização finita, mas, ao mesmo tempo, evidentemente não tem, nessa realização finita, a sua autêntica incorporação de essência. Somente por sermos capazes de ter a percepção de que aquilo que essas perfeições puras são em si mesmas está presente nas suas encarnações finitas apenas fracamente é que podemos entender o seu caráter como perfeições puras. O que essas perfeições são em si mesmas está primariamente, e num certo sentido exclusivamente, realizado na sua forma infinita: ora, qualquer conhecimento limitado não é real e plenamente conhecimento, etc. A "via positiva", no sentido de atribuir ser e conhecimento a um ente, é aqui apenas aplicável ao ente infinito, enquanto a "via 
negativa" se aplica, aqui, apenas ao ente finito, que é, mas também não é, tem conhecimento, mas também carece de conhecimento, etc.

Nesse sentido, as perfeições puras são diretamente opostas às perfeições mistas, na medida em que o que é formalmente significado no conceito de uma perfeição mista é primariamente e, num certo sentido, exclusivamente realizado em entes finitos. Dentro do ente infinito, apenas alguma coisa radical e completamente diferente pode ser posta, a qual contém em si mesma as perfeições essencialmente limitadas apenas numa maneira super-eminente, isto é, o ente infinito não possui diretamente essas naturezas e perfeições essencialmente limitadas, mas, por outro lado, não carece de nenhum bem que está presente nelas. Assim, com as perfeições mistas, a "via negativa" é válida para o ente absoluto, e a "via affirmationis" para o ente finito.

Com as perfeições puras, dá-se o caso oposto, como mantém Tomás de Aquino. Aqui, a "via positiva", ou a "via affirmationis", é válida apenas para o ente absoluto, o qual "apenas é" e o qual apenas é bom, enquanto a "via negativa" é válida para o ente finito.

\subsubsection{As perfeições puras são "irredutivelmente simples" - Duns Scotus como descobridor de "fenômenos originais" 37 irredutíveis?}

Considere-se a seguinte passagem:

Omnis perfectio simpliciter est simpliciter simplex. Probatur, si est aliquo modo resolubilis in distincta, sint A et B, neutrum potest esse perfectio simpliciter simplex, quia tunc unum non faceret per se unum cum relinquo, quia non est per se unum ex quibuscumque distinctis, nisi unum sit sicut actus et aliud sicut potentia. ${ }^{38}$

Toda perfeição pura é irredutivelmente simples, diz Duns Scotus. Ele quer dizer com isso ao menos que toda perfeição pura é aquilo que os fenomenólogos chamaram de um "dado original último", um "Urphänomen". Nenhuma essência de uma perfeição pura permite que ela mesma seja reduzida a ou seja deduzida de alguma outra coisa, ou que ela seja definível através de alguma outra coisa, mais simples (o modo no qual, por exemplo, as "espécies simples" que não são "simpliciter simplex" são definidas através do gênero e da "differentia specifica"). Nós tocamos, numa perfeição pura, numa coisa última e simples, que não pode, de maneira nenhuma, ser pensada como composta de outros predicados, ou de outras perfeições.

A simplicidade necessária e irredutível de toda perfeição pura pode ser melhor entendida por meio de um argumento que assume como ponto de partida a sua essência universal. Se uma perfeição pura não fosse um dado último, original, no sentido dos fenomenólogos, ou irredutivelmente simples, na terminologia de Duns Scotus, então ela poderia apenas consistir de outras perfeições puras. Pois é evi-

7 No original, a expressão é "Urphenomena". N. do T.

Quodlibet 1, n. 4. 
dente que uma perfeição pura não pode consistir de perfeições essencialmente limitadas, "mistas". Contudo, fossem as outras perfeições, das quais uma dada perfeição pura $X$ é composta apenas acidentalmente, ligadas com a "perfectio simpliciter" composta, então elas constituiriam juntas apenas uma unidade acidental, o que contradiria o seu estatuto como uma perfeição pura. Um mero conglomerado, uma mera unidade acidental de várias perfeições não pode possivelmente ser uma perfeição pura e potencialmente infinita. Portanto, deve ser o caso, afirma Scotus, que toda perfeição pura possui uma simplicidade irredutível e última.

Aqui, ergue-se reconhecidamente a questão se a alternativa sobre a qual repousam as premissas e a conclusão desse argumento é de fato uma alternativa verdadeira. Não poderia haver uma unidade e uma identidade essencial e necessária (isto é, não-acidental) de todas as perfeições puras? Scotus certamente não exclui essa possibilidade. Mas, isso não leva a uma redutibilidade de todas as perfeições puras a uma única perfeição singular? Esta questão deve permanecer, ao menos neste ponto, não-respondida. Seja como for, uma mera unidade acidental de perfeições puras pode, certamente, ser excluída.

Mesmo que as perfeições puras não fossem partes físicas, mas antes partes metafísicas (tais como ato e potência) de um todo, elas ainda seriam imperfeitas e se exigiriam mutuamente para a sua própria perfeição. Toda concepção das perfeições puras, como compostas ou como partes de um todo, contradiz as características essenciais das perfeições puras que já elaboramos.

As distinções da terceira Investigação Lógica de Husserl, entre partes dependentes e independentes, bem como a distinção que Duns Scotus faz entre distinção real e "distinctio formalis cum fundamento in re", seria muito útil para um aprofundamento posterior da doutrina da impossibilidade de que as perfeições puras sejam um resultado de uma composição de partes. Por causa do escopo limitado deste estudo, entretanto, devemos desistir de uma aplicação dessa distinção no que se refere ao nosso problema.

A irredutibilidade das perfeições puras a qualquer outra, e a sua realidade simples, última, levanta, porém, muitos problemas. O mais importante desses problemas - como podemos conciliar conceitualmente a unidade irredutível de toda perfeição pura com a sua compatibilidade mútua e a sua unidade última (que, ao mesmo tempo, pressupõe uma simplicidade última, na qual as perfeições puras não podem estar como uma mera parte) - pode ser respondido apenas após uma consideração do ente absoluto e infinito como uma unidade perfeita mas nãoreducionista de todas as perfeições puras.

A unidade "simipliciter simplex" de todas as perfeições puras e, ao mesmo tempo, a sua distinção recíproca, e, ademais, a diferenciação entre perfeições puras individuais e, ao mesmo tempo, a simplicidade com a qual elas são unas consigo mesmas e que une todos os seus vários momentos essenciais, isso constitui, talvez, o problema metafísico mais profundo que uma metafísica das perfeições puras, autenticamente fenomenológica, orientada aos dados, pode confrontar. No entanto, nem a variedade dos momentos essenciais de toda perfeição pura (tais como os primeiros princípios do ente e as propriedades transcendentais do 
ser do "ens", ou as várias características essenciais da liberdade) nem a simplicidade delas deve ser negada. O problema da coincidência, acima mencionado, e, ao mesmo tempo, a multiplicidade das perfeições puras permitem um tratamento detalhado apenas em conjunção com uma metafísica do ente absoluto. ${ }^{39}$

Neste contexto, também não trataremos de uma outra característica essencial das perfeições puras, que é considerada por Duns Scotus: a comunicabilidade de todas as perfeições puras. Essa característica das perfeições puras nos levaria para longe demais da esfera da filosofia: levar-nos-ia ao domínio da teologia. ${ }^{40}$

\subsection{Os transcendentais e as perfeições puras como irredutíveis às "passiones entis qua entis"}

A metafísica, em sentido autêntico, e, acima de tudo, o conhecimento de Deus seriam impossíveis, bem como também o nosso pensamento seria limitado à apreensão de categorias do ser individuais e ao reino do finito que se adequa às nossas categorias essencialmente limitadas, sem a existência daqueles atributos do ente e dos primeiros princípios que os escolásticos chamam de "transcendentais". Afinal, a aplicação deles não está limitada a categorias ou a modalidades específicas do ser.

Duns Scotus não começa a partir da caracterização medieval usual dos transcendentais como sendo exclusivamente aquelas propriedades que são encontradas em todo ente, absolutamente. Antes, ele apresenta o problema numa maneira que é essencialmente mais extensa, isto é, como uma questão sobre todas aquelas propriedades do ser que não são necessariamente limitadas a uma categoria ou a uma esfera determinada do ser.

Essa concepção mais ampla dos transcendentais, que Duns Scotus foi, talvez, o primeiro a propor na história da filosofia, é também a base da sua metafísica personalista da vontade e do amor. A questão que ele coloca é a seguinte: é possível não apenas descobrir atributos transcendentais, que são o ente ou coextensivos com o ente ("coextensiva enti"), que devem existir em todo ente, mas também obter o entendimento de atributos que, de fato, não existem em todo ente, mas que, contudo, não possuem limitações ou restrições essenciais? Apenas se essa questão é respondida de forma afirmativa, é possível uma metafísica da liberdade e do amor como perfeições puras que também existem em Deus.

Cf. Josef SEIFERT, Gott als Gottesbeweis; idem, Essere e persona, Capítulo 5.

A percepção filosófica da comunicabilidade de todas as perfeições puras é, em Duns Scotus, motivada teologicamente, o que de modo algum exclui que, aqui, possam ser encontradas também certas idéias filosóficas. Começando com o mistério da Trindade, Scotus enfatiza que as características singulares das pessoas divinas e da "pessoa" na sua "haecceitas" e individualidade insubstituível não podem jamais ser uma "perfeição pura". Ora, se toda especificação, que é própria apenas de uma pessoa específica, fosse uma perfeição pura, então todas as outras pessoas, mesmo a divina, seriam imperfeitas, porque elas careceriam precisamente dessa perfeição. Isso é verdadeiro em particular de toda individualidade finita, bem como da participação de uma natureza finita nas perfeições puras. 
Duns Scotus categoriza os transcendentais, de acordo com a extensão acima mencionada do problema dos transcendentais, de maneira disjuntiva. Ele afirma que todas as determinações que são atribuíveis a entes independentemente da distinção entre infinito e finito, ou todas aquelas propriedades que são próprias ao ente infinito apenas, são transcendentais, isto é, situam-se além de todas as determinações e de todos os limites de gêneros ou espécies. ${ }^{41}$

Com essa caracterização dos transcendentais, a distinção, na obra de Scotus, entre as "propriedades transcendentais do ente" e as "perfeições puras" se torna óbvia: todos os transcendentais são necessariamente também perfeições puras, e todas as perfeições puras são "eo ipso" transcendentais. Isso se segue da caracterização essencial nova e mais profunda que Scotus dá aos transcendentais. Nós reconheceremos mais tarde que, em adição àquelas perfeições transcendentais puras, que são possuídas por todos os entes, e àquelas que são atribuíveis apenas a Deus, há um terceiro grupo de transcendentais (tais como ser uma pessoa, o conhecimento, a liberdade, etc.), que são aqueles atribuíveis a alguns entes finitos e ao ente absoluto, mas que têm um caráter profundamente transcendental, no sentido de que são perfeições puras e livres de todas as limitações essenciais. Duns Scotus desenvolve, na verdade, uma filosofia da liberdade, baseada na intuição deste terceiro grupo de perfeições puras (=transcendentais), embora ele não distinga explicitamente este terceiro grupo de transcendentais (que não são nem coextensivos com o ente nem exclusivamente divinos) dos outros dois.

Junto com Duns Scotus, podemos distinguir posteriormente, a partir de um outro ponto de vista, cinco diferentes tipos fundamentais de propriedades transcendentais do ente:

1. O primeiro e mais fundamental transcendental, como o lar e a fonte de todos os transcendentais, é o próprio "ens" ("ente"). Neste transcendental, estão enraizadas todas as outras determinações transcendentais do ente, em particular aquelas que são coextensivas com o ente. "Ens" é ele mesmo posteriormente determinado pela diferença entre ser e ente, por um lado, e entre ente e essência, por outro lado.

2. Em segundo lugar, Duns Scotus distingue a partir de "ens", como o primeiro transcendental, aqueles transcendentais que são coextensivos com o ente. Estes são aqueles que foram geralmente reconhecidos pelos escolásticos, em adição a "ens", como determinações transcendentais do ser. Entretanto, como já afirmamos, Duns Scotus não considera nem essas características nem o próprio "ens" como transcendentais primariamente pelo fato de serem comuns a todos os entes. Antes, isso é apenas um dos muitos modos de transcender o categorial ou qualquer outro tipo de limitação de ser. Certamente, porque as categorias transcendentais do ser, que são coextensivas com os entes, devem ser encontradas em

${ }_{11}$ Ordinatio I d. 8, q. 3, p. 206, n. 113: "Ergo quaecumque conveniunt enti ut indifferens ad finitum vel infinitum, vel ut est proprium enti infinito, conveniunt sibi non ut determinatum ad genus, sed ut prius, et per consequens, ut ens transcendens et extra omne genus". 
todos os reinos do ser, elas são também "eo ipso" não-limitadas a qualquer tipo determinado de ser, e não possuem limitações a categorias singulares ou esferas singulares do ser. Entretanto, não é primariamente esse momento de generalidade absoluta que as constitui como transcendentais, mas muito mais a possibilidade de serem ilimitadas, o que também é atribuível a muitas outras características do ser, que não são absolutamente gerais, mas que são, contudo, perfeições puras, tais como a liberdade, por exemplo. Duns Scotus escreve: "Non oportet ergo transcendens ut transcendens dici de quocumque ente", isto é, "não é necessário, portanto, que o transcendental como transcendental seja predicável de todo ente". ${ }^{42}$

Que esse caráter transcendental ou "transcendente" não lhes é atribuído com base no fato de serem encontrados em todos os entes, mas antes por razão da perfeição "pura" (não essencialmente limitada) deles, naturalmente não implica que as "passiones entis qua entis" não incorporam um sentido único e significativo de "transcendental", na medida em que essas propriedades (e não as outras perfeições puras) são os princípios que fundam a comunidade e a unidade de todos os entes.

Enquanto a lista mais longa dos transcendentais coextensivos, em Tomás de Aquino, contém sete transcendentais, Duns Scotus os reduz a apenas três; se "ens" (que ele localiza num grupo separado) for incluído, tal como na lista tomasiana de sete transcendentais, então Duns Scotus reduz aquele número a quatro. ${ }^{43}$ Nós também não queremos, no contexto da presente discussão, entrar numa análise crítica, se talvez alguns dos transcendentais (tais como o "bonum" ou o "pulchrum") são "transcendentais coextensivos com o ente" apenas num sentido limitado do termo, na medida em que todos os entes os possuem, mas apenas no sentido de que em todos os entes há alguma coisa (algum resquício) deles. ${ }^{44}$

${ }^{42}$ Ordinatio I d. 8, q. 3, p. 207, n. 115. Ora, dado que o ente absoluto, com base na sua infinitude ou caráter absoluto, está além de todos os limites de qualquer constituição meramente categorial do ser e de quaisquer outros limites, todos aqueles atributos que são encontrados no ente divino infinito, independentemente se são encontrados em quaisquer outros entes ou são partilhados por quaisquer outros entes, devem ser afirmados como transcendentais.

43 Cf. THOMAS AQUINATIS, Quaestiones disputatae de veritate q. I, a. 1; Edith STEIN, Endliches und ewiges Sein. Versuch eines Aufstiegs zum Sinne des Seins, in: L. GERBER (Hrsg.), Edith Steins Werke, Band II, p. 302s. 308s. Cf., como parte desta discussão, John CROSBY, The idea of value and the reform of the traditional metaphysics of Bonum, in: Aletheia, p. 231-339.

44 A idéia de um transcendental limitado significaria que esse transcendental é encontrado em todos os entes, mas que nem todo ente na sua realidade completa pode ser caracterizado por meio desse transcendental. Que o "bonum" e o "pulchrum" são transcendentais, apenas neste sentido limitado, isso é sugerido pelo fato de que males, tais como dor, morte, sofrimento e maldade, realmente existem no mundo. Embora eles sejam perversões e deformidades do ente como portador de valor e pressuponham esse ente, eles, contudo, não têm simplesmente falta de realidade. Ao mesmo tempo, o mal do sofrimento ou da maldade como tal certamente não possui as características do Bom e do Belo. Os transcendentais não são - considerados nesse ponto de vista - simplesmente em todas as coisas, na medida em que elas são, muito embora nenhum ente possa ser completamente privado deles, e, nesse sentido, eles são determinações transcendentais de todos os entes. Cf. Josef SEIFERT, Essence and existence, in: Aletheia, p. 442-3, nota 150a. 
Com a redução, por Duns Scotus, dos três transcendentais tomasianos "res" ("essentia"), "aliquid" ("non nihil"; "aliud quid") e "unum" ao "unum", ergue-se a questão se ele, aqui, descobriu uma redutibilidade autêntica de diferentes transcendentais a um, ou se ele reduziu a um três momentos irredutivelmente distintos, os quais Edith Stein elaborou com grande precisão fenomenológica. Além de "ens" e "unum", Duns Scotus também mantém firme o "verum" e o "bonum", em que ainda é necessário perguntar se o fato de ter riscado o "pulchrum" (isto é, de ter reduzido este ao "bonum") é justificado.

3. Em terceiro lugar, tem-se a investigação filosófica de Duns Scotus de um terceiro tipo fascinante de "transcendental", que ele chama de "transcendentais disjuntivos", dos quais, na sua opinião, deve haver uma quantidade infinita, e cujo significado mais profundo, um significado decisivo para o problema da analogia e da univocidade, reside na disjunção que distingue o finito do infinito, o ente que subsiste em si mesmo distinto do ente que subsiste em outro, o ente temporal do ente eterno. Os transcendentais disjuntivos, nesse sentido, ditam, em outras palavras, que todo ente deve ser ou absoluto ou não-absoluto. Essas "disjunções transcendentais", como eu prefiro chamá-las (porque não existe, de fato, uma determinação transcendental específica que é aqui atribuída a todos os entes, mas apenas aquela característica de que todo ente respectivamente deve possuir um atributo de um par específico de opostos contraditórios), põem problemas filosóficos fundamentais, que, aqui, no entanto, devem ser excluídos da nossa discussão.

4. De importância muito maior para nós, aqui, porque se trata da base da filosofia da vontade e do amor de Duns Scotus, é, acima de tudo, um quarto grupo de propriedades trasncendentais que Scotus distingue, e que Anselmo de Cantuária já tinha trazido à luz antes dele. Eu me refiro àquelas "perfeições puras" que são apenas perfeições puras e que não pertencem a nenhum dos outros grupos de transcendentais. Ora, as perfeições puras como tais são, na verdade, não um grupo separado de transcendentais, mas, antes, constituem o cerne mais íntimo de todos os transcendentais. O próprio ente e todas as determinações transcendentais do ente coextensivas com o ente são também perfeições puras. De semelhante modo, um lado respectivo dos "disjuntivos transcendentais" está constituído por uma perfeição pura.

Mesmo se as perfeições puras constituem o núcleo de todos os transcendentais e são coextensivas com todos os transcendentais, no sentido discutido acima, existem, ainda, em adição aos primeiros três tipos de transcendentais, determinações transcendentais tais que se estendem, para além do ente absoluto, a apenas alguns entes finitos, tais como a pessoa, por exemplo, e que, portanto, não caem em nenhum dos primeiros três grupos de determinações transcendentais do ser.

5. Enquanto todas (e, segundo Duns Scotus, apenas) as perfeições puras e todos os transcendentais são atribuíveis a Deus, existem, finalmente, aquelas perfeições puras exclusivamente divinas (tais como onisciência, onipotência, infinitude absoluta, aseidade, etc.). Estas últimas são atribuíveis exclusivamente ao ente absoluto. 


\section{A filosofia scotista do bem como o fundamento da filosofia da liberdade}

Voltemo-nos à investigação do transcendental fundamental chamado "bonum". O transcendental "bonum" é de significado crucial, tanto para a metafísica como para a ética, para uma filosofia da liberdade como para uma filosofia do amor. Além disso, toda a idéia de perfeições puras está necessariamente conectada com a perfeição pura do "bonum" e requer um conceito adequado de bem e de valor.

Em Tomás de Aquino, o bem (o valor) é definido como uma propriedade transcendental do ser, não em si mesma ("in se"), tais como ente e essência, mas em relação a alguma outra coisa ("ad aliud"), a saber, como relativo à vontade e, mais propriamente, aos apetites. O bem é concebido como ente qua "appetibile".

Se o valor, no primeiro e mais fundamental sentido, é apreendido como a importância objetiva e intrinsecamente positiva de um ente, ou mesmo, mais precisamente, é a preciosidade intrínseca do ente, então é claro que a sua bondade está completamente fundada na essência particular - e, em muitos casos, na existência real - de um ente.

Acerca do bem objetivo para uma pessoa, é verdade que a importância de um ente não depende do fato de que o ente é em si mesmo, mas apenas, por assim dizer, do ente "na sua relação com" um outro ente. Em muitos casos de bens objetivos para as pessoas, isso significa que o bem se dispõe assim em relação aos seus esforços, impulsos, ou à sua felicidade. Tal tipo de importância realmente não caracteriza um ente em si mesmo ("in se"), mas apenas "ad alia". Esse é o modo como Tomás de Aquino caracteriza o "bonum" em geral, a saber, como um transcendental não "in se", mas sim "ad aliud", isto é, em relação a um "appetitus".

Em diferença radical a isso está a importância do valor, a qual apenas torna possível um conceito de bem verdadeiramente metafísico. Essa importância caracteriza um ente na sua própria natureza mais íntima. Aqui, seria sem sentido dizer que um ente que é valioso é, em si mesmo, neutro. Tomás de Aquino explica, em De veritate q. 21, que o ente tem bondade apenas em relação a um "appetitus", na medida em que é, pois, um "appetibile". Duns Scotus, ao contrário, reconhece claramente que a bondade é uma propriedade intrínseca do ente, e não somente relativa aos apetites. Como veremos, esse é o fundamento da filosofia scotista da liberdade como perfeição pura, fundamento este que dá espaço à infinitude.

Nem o prazeroso nem o bem como atrativo aos nossos apetites, mas a bondade em si mesma é o "bonum" transcendental. E apenas por essa razão também o belo pode ser subsumido sob o "bonum", segundo Duns Scotus. Pois o "pulchrum" também pertence àquela esfera do importante positivamente em si mes-

\footnotetext{
45 Nós prescindimos, aqui, de um outro tipo de fundamento do "bonum", na medida em que ele é uma perfeição na atualidade do "esse", ou a partir de uma identificação do "bonum" com o ato de ser real, que ocorre numa tese tomística mais objetivista, uma tese que John Crosby e outros autores criticaram, fazendo uso de um conceito análogo àquele que nós também aceitaríamos, como uma forma de "naturalismo".
} 
mo, isto é, do valor, no sentido de Dietrich von Hildebrand. Nesse sentido, o "pulchrum" certamente decai no "bonum", na esfera do "bonum", entendido, num sentido mais amplo, como o bem em si mesmo, ou como valor. ${ }^{46}$

\section{A liberdade como perfeição pura e pessoal, de acordo com a metafísica da liberdade de Duns Scotus}

Duns Scotus insiste em tais perfeições pessoais, como conhecimento, liberdade e amor como sendo perfeições puras. ${ }^{47}$ As percepções fundamentais de Duns Scotus sobre a espiritualidade e a perfeição da vontade livre constituem uma parte central das suas idéias filosóficas. ${ }^{48}$ Sobre a vontade, note-se o seguinte texto:

Tome-se, por exemplo, a noção formal de "sabedoria", "intelecto", ou "vontade". Tal noção é considerada, antes de mais nada, simplesmente em si mesma e absolutamente. Porque essa noção não inclui formalmente nenhuma imperfeição ou limitação, as imperfeições associadas a ela nas criaturas são removidas. Mantendo essa mesma noção de "sabedoria" e "vontade", atribuímo-las a Deus - mas no grau mais perfeito. Por conseguinte, todo inquérito concernente a Deus está baseado na suposição de que o intelecto tem [de Deus] o mesmo conceito unívoco que ele obtém a partir das criaturas. ${ }^{49}$

\subsection{A liberdade como perfeição pura por causa do seu objeto, o bem, é uma característica intrínseca do ente, e não é dependente de quaisquer apetites do sujeito}

A compreensão de valor (ou do bem), por parte de Duns Scotus, como uma propriedade transcendental do ente "in se", ${ }^{50}$ isto é, como uma característica in-

${ }^{46}$ Cf. Edith STEIN, Endliches und ewiges Sein. Versuch eines Aufstiegs zum Sinne des Seins, in: L. GERBER (Hrsg.), op. cit.

${ }^{47}$ Ordinatio I d. 3, p. 1, q. 1-2, p. 25, n. 39

${ }^{48}$ Cf. Walter HOERES, Der Wille als reine Vollkommenheit nach Duns Scotus, p. 149s. 205s. Cf. também Roberto Hofmeister PICH, Der Begriff der wissenschaftlichen Erkenntnis nach Johannes Duns Scotus, p. 22.

49 Ordinatio I d. 3 , p. 1, q. 1-2, p. 25, n. 39.

${ }^{50}$ Cf. também Ordinatio III d. 33, q. un., n. 6: "Voluntas autem habet pro objecto bonum ostensum ab intellectu, quod est bonum universale, quod est bonum simpliciter". Cf. também Ordinatio IV d. 49, q. 5, n. 6.

Cf. Ordinatio IV d. 49, q. 10, n. 15: "Intellectus potest cognoscere rationem illam boni, non ut ad finem ordinatus, sed ut in se est quoddam bonum; et sic voluntas potest ipsum velle non in ordine ad beatitudinem". Cf. também a excelente análise que Walter Hoeres oferece a esta doutrina de Duns Scotus; cf. ibidem, p. 149s. A seguir, cito algumas das mais significativas passagens da análise de Walter HOERES, op. cit., p. 150-2, desta doutrina de Scotus (em tradução para o inglês, por Katharina Fedoryka): "In contrast to this, Scotus conceives of the will as an autonomous potency, whose aim in no way simply coincides with that of the being in which it is rooted. The autonomy of the will is rather grounded in its specific, material nature, which allows it to be in rational ordination towards the good, and in that this nature is a pure perfection. This essential content allows the will to act in a manner that is truly rational and objective in relation to goods; by virtue of the pure perfection of this content, this stance is extended to all goods, to the good itself. The capacity for such a stance makes the will something completely different from all other faculties of natural sensible striving, for 'the will alone among all appetities (appetitus) can desire something good for its own sake, and therefore there is no similarity between the will and those other 
trínseca do ente, é a principal razão por que não apenas o "bonum" pode ser uma perfeição pura capaz de infinitude, ao invés de estar limitada à natureza dos apetites do sujeito, mas também por que a liberdade, na medida em que acarreta uma relação adequada ao valor intrínseco das coisas, pode ser uma perfeição pura. ${ }^{51}$ Duns Scotus descobriu que nós também podemos reivindicar a capacidade de dar uma resposta-de-valor devida, ${ }^{52}$ isto é, a capacidade de responder a um bem intrínseco que não é pretendido apenas como um meio para a felicidade: "Intellectus potest cognoscere rationem illam boni, non ut ad finem ordinatus, sed ut in se est quoddam bonum; et sic voluntas potest ipsum velle non in ordine ad beatitudinem". 53

appetites'. Only the will, therefore, can affirm something for its own sake; its object is therefore not only that particular good of its own perfection, but the general good, i.e., the Good itself; insofar as we think of the convertibility of ens and bonum, the object of the will is being itself. This follows from the fact that the will can evaluate everything for its own sake, and from the fact that the purely absolute good, i.e., the good which is not constituted through the relationship with something other such as my own perfection, for example, is convertible with being.

And so the will can, on the basis of its natural essence, i.e., without the addition of caritas, love God above all else, but in the same way, it can will every other good, without having to set itself in relation, either implicitly or explicitly, to the final end of beatitudo. Through this also is Scotus' doctrine of the will differentiated from that of St. Thomas, for whom the finite goods always appear as means for a final end. The ecstatic structure of the will in Scotus' thought manifests itself precisely in that it is able to affirm every good - no matter how small it is - for its own sake... This affirmation of the object in its specific place in the hierarchy of values is only possible through the rationality of the will, which is able to do justice to the object in itself, without reference to its own perfection. With this definition of the rationality of the will as the ability to do justice to every good in its own terms, we have fixed upon the deepest grounds for the ability of will as rational capacity to prefer one good to another. The doctrine of the capacity to affirm and to do justice to a good purely for its own sake allows Scotus also to stress emphatically that the will is spiritual and rational not only through participation, but in itself. For if the essence of spirit consists in ecstatically reaching out to another in its individuality, then this applies to the intellect equally as well as to the will. Since the ability for self-determination has its measure and its direction in the inner rationality of the will through which freedom is first made possible, as we have said, one can also characterize freedom as the ability to do justice to every thing".

Na sua análise, Hoeres mostra muito bem de que modo a "affectio iustitiae" oferece a ordem interna para a "affectio commodi", ao fazer da motivação para a nossa própria vantagem, prazer e felicidade uma motivação ordenada. Esta doutrina de Scotus, de acordo com a qual o "bonum" transcendental não é somente bom em relação a um apetite, mas em si mesmo, e de acordo com a qual a razão mais profunda, na verdade a única razão, para a liberdade da vontade reside na justiça da vontade, que permite que a pessoa livre afirme os entes por causa da sua própria bondade intrínseca, está entre as mais brilhantes contribuições que Duns Scotus faz para a filosofia do bem e para a antropologia e ética filosóficas.

${ }^{51}$ Cf. Ordinatio III d. 33, q. un., n. 6: "Voluntas autem habet pro objecto bonum ostensum ab intellectu, quod est bonum universale, quod est bonum simpliciter". Cf. também Ordinatio IV d. 49, q. 5, n. 6. Cf. também a excelente análise que Hoeres oferece a esta doutrina de Duns Scotus; cf. ibidem, p. $149 \mathrm{~s}$.

52 Cf. Dietrich VON HILDEBRAND, Ethics, Capítulos 17-18.

53 Cf., semelhantemente, Ordinatio IV d. 49, q. 10, n. 15. 


\subsection{A liberdade é uma perfeição pura porque ela pode ser motivada, não pelo intuito de satisfazer os apetites ou "affectio commodi", mas pela "affectio iustitiae"}

Que a vontade livre pode ser motivada pelo valor intrínseco das coisas e, acima de tudo, das pessoas também torna possível a dignidade espiritual da pessoa e a liberdade que afirma os entes por causa deles mesmos. Além do mais, o escopo infinito da escala de objetos de atos livres é tornado possível pela capacidade da pessoa livre de afirmar o bem intrínseco por causa dele mesmo. Se o bem dependesse dos nossos apetites, a vontade livre seria sempre restrita a uma fina fração do mundo universal de bens, a saber, àquela parte dela que está relacionada à felicidade finita do sujeito, e não poderia ter o bem em si mesmo, mas apenas o bem para o sujeito como o seu fim último. Portanto, a vontade seria muito mais restrita do que o intelecto, e não uma perfeição pura. Porém, uma vez que ela se estende a todos os bens, incluindo o bem infinito, em si mesmos, ela é uma perfeição pura e até mesmo mais elevada do que o intelecto: primeiro, porque o valor da sua resposta, devido ao bem, é maior do que o valor intelectual do conhecimento do bem; e, em segundo lugar, porque o seu escopo é mesmo mais amplo do que aquele do intelecto, porque o ato e o amor da vontade podem abarcar também todos os aspectos do bem infinito que a razão humana não pode compreender.

A tese de que a vontade livre é uma perfeição pura pode ser justificada apenas se o "importante em si mesmo", o bem como valor em si mesmo, ou o bem como portador de um valor intrínseco e objetivo, é reconhecido como objeto da vontade - em contradistinção ao "bem objetivo para a pessoa", isto é, ao "ens qua appetibile", que não é "em si mesmo" ("in se") bom, mas, antes, bom apenas em relação ao apetite ("ad aliud"), e, portanto, mais restrito -, e ainda se a vontade pode afirmar o bem "in se".

\section{A descoberta por Scotus da natureza não-eudemonística do amor e do "princípio personalístico" ("persona est affirmanda propter seipsam") como condição da ética e do mandamento moral mais elevado de amor a Deus}

Todas essas percepções estão intimamente relacionadas à filosofia do amor de Scotus. ${ }^{54}$ No ato de amor, as exigências da relação devida são preenchidas numa maneira única, na medida em que o amor é direcionado para pessoas que são afirmadas por causa de si mesmas. Acima de tudo, no ato de amor a Deus, que

54 A análise mais significativa desta doutrina de Scotus acerca das perfeições puras foi apresentada por Walter HOERES, op. cit., p. 149s. 
Scotus julga possível mesmo por natureza e no qual uma pessoa dá o seu ser inteiro a Deus, vive uma encarnação perfeita desta relação devida. ${ }^{55}$

O amor não pode ser concebido como sendo motivado apenas pela própria vantagem ou felicidade ("affectio commodi"), mas repousa inteiramente na "affectio iustitiae", numa motivação de justiça intrínseca e adequação. Se não vemos isso, falhamos em entender o amor, como Duns Scotus vê com clareza extraordinária e numa perspectiva fenomenológica para com as coisas mesmas. Esta "volta às coisas mesmas" se mostra de forma particularmente impressionante na análise de Scotus acerca do amor. ${ }^{56}$

Além disso, apenas tal filosofia da autotranscendência do amor e da sua motivação pela "affectio iustitiae" torna compreensível que devemos amar o próximo como a nós mesmos e a Deus acima de tudo. Este primeiro mandamento pode apenas ser cumprido, se Deus não é apenas amado como o nosso próprio bem, muito menos como um meio para a nossa própria felicidade. Afinal, em tal perspectiva eudemonística nós jamais poderíamos amar a Deus mais do que a nós mesmos, porque os apetites para a felicidade e, portanto, o eu limitado seriam a única medida e fonte derradeira do nosso amor do bem divino. Portanto, um amor a Deus mais do que o amor a nós mesmos se tornaria intrinsecamente impossível, razão pela qual Duns Scotus pensa que a ética eudemonística não é apenas filosoficamente falsa, mas também teologicamente herética, dado que, na sua última conseqüência, ela dissolveria e negaria o primeiro mandamento. ${ }^{57}$

Num certo sentido, aquelas percepções de Duns Scotus poderiam muito bem ser comparadas à filosofia da liberdade e da transcendência de Karol Wojtyla; ${ }^{58}$ Duns Scotus vê a autonomia e a perfeição da vontade como enraizada numa transcendência especial, em virtude da qual a vontade pode responder ao bem intrínseco. Ela está racionalmente ordenada ao bem em si mesmo, a todos oS bens, e ao Bem absoluto acima e além do papel deles para a felicidade do sujeito. A capacidade extática e autotranscendente da vontade de afirmar bens intrínsecos

55 A qual, como crê o cristão, pode apenas se tornar mais perfeita do que ela é, dentro da esfera de objetos e experiências naturais, se ela é elevada pela graça e se ela alcança a perfeição última pela participação no mistério do amor do próprio Deus encarnado.

${ }^{56}$ A dimensão fenomenológica da teoria scotista das perfeições puras e do amor é trabalhada com grande exatidão por Walter HOERES, Der Wille als reine Vollkommenheit nach Duns Scotus, em especial p. 17s.

57 Cf. também ANSELMUS, Proslogion und Ad Proslogion, in: Franciscus Salesius SCHMITT (Hrsg.), S. Anselmi Opera Omnia, Stuttgart/Bad-Cannstatt, Friedrich Frommann/Günter Holzboog, 1968, Band I, p. 89-139; cf. também Josef SEIFERT, Essere persona come perfezione pura. Il Beato Duns Scoto e una nuova metafisica personalistica, in: De Homine - Dialogo di Filosofia 11, p. 57-75; idem, Essere e persona, Milano, Vita e Pensiero, 1989.

58 Cf. Karol WOJTYLA, The Acting Person, Boston, Reidel, 1979; cf. também o texto corrigido, autorizado pelo autor (e não publicado), na cópia oficial na Biblioteca da International Academy of Philosophy in the Principality Liechtenstein, Schibbogga 7 B-C, Bendern, Liechtenstein. Cf. também Josef SEIFERT, Karol Cardinal Karol Wojtyia (Pope John Paul II) as Philosopher and the Cracow/Lublin School of Philosophy, in: Aletheia, p. 130-99. 
por causa deles mesmos é a condição última e o fundamento do seu caráter como perfeição pura. ${ }^{59}$

De acordo com Scotus, a "affectio iustititae" provê também a ordem interna para a "affectio commodi", ao tornar a motivação pela nossa própria vantagem, prazer e felicidade uma motivação ordenada. ${ }^{60}$

Essa doutrina de Scotus, de acordo com a qual o "bonum" transcendental não é apenas bom em relação a um apetite, mas em si mesmo, e de acordo com a qual a razão mais profunda para a liberdade da vontade reside na adequação e na justiça da vontade, que permite que a pessoa livre afirme os entes por causa da própria bondade intrínseca deles, está entre as contribuições mais destacadas de Duns Scotus para uma adequada filosofia do bem, para uma antropologia e uma ética filosóficas, e para uma filosofia do amor como suprema perfeição pura.

Traduzido do inglês por Roberto Hofmeister Pich

\section{Referências}

\section{Fontes}

ANSELMUS. Proslogion und Ad Proslogion. In: SCHMITT, Franciscus Salesius (Hrsg.). S. Anselmi Opera Omnia. Stuttgart/Bad-Cannstatt, Friedrich Frommann/Günter Holzboog, 1968, Band I, p. 89-139.

DUNS SCOTUS, Ioannes. Opera omnia I. Ordinatio: prologus. Civitas Vaticana, Typis Polyglottis Vaticanis, 1950

. Opera omnia II. Ordinatio - Liber primus: distinctio prima et secunda. Civitas Vaticana, Typis Polyglottis Vaticanis, 1950.

Opera omnia III. Ordinatio - Liber primus: distinctio tertia. Civitas Vaticana, Typis Polyglottis Vaticanis, 1954.

Opera omnia IV. Ordinatio - Liber primus: a distinctione quarta ad decimam. Civitas Vaticana, Typis Polyglottis Vaticanis, 1956.

DUNS SCOTUS, Johannes. Opera omnia X: Ordinatio IV d. 43 - Ordinatio IV d. 50. (Reprografischer Nachdruck der Ausgabe Lyon 1639). Hildesheim, Georg Olms Verlagsbuchhandlung, 1968.

Opera omnia XII: Quaestiones quodlibetales. (Reprografischer Nachdruck der Ausgabe Lyon 1639). Hildesheim, Georg Olms Verlagsbuchhandlung, 1969.

DUNS SCOTUS, John. A Treatise on God as First Principle. Tradução de Allan B. Wolter. Disponível online: <http://www.ewtn.com/library/THEOLOGY/GODASFIR.HTM>.

\section{Literatura secundária}

BETTONI, Efrem. Duns Scotus: the basic principles of his philosophy. Translated and edited by B. Bonansea. Washington (D.C.), The Catholic University of America Press, 1961.

59 Cf. o texto extraordinário de Walter HOERES, op. cit., p. 150-152. Cf. acima, na nota 50, a tradução de Katharina Fedoryka para o inglês.

Esta idéia, mais uma vez, é bastante similar à filosofia da integração de Karol Wojtyla. 
BOLZANO, Bernard. Paradoxien des Unendlichen. 2. Auflage. Hrsg. von F. Prihonský. Mit Einleitung, Anmerkungen, Registern und Bibliographie neu herausgegeben von Bob van Rootselaar. Hamburg, Felix Meiner Verlag, 1975

CROSBY, John. The idea of value and the reform of the traditional metaphysics of Bonum. In: Aletheia. I,2 (1977), p. 231-339.

CROSS, Richard. Duns Scotus. New York/Oxford, Oxford University Press, 1999.

FRANK, William A. Duns Scotus on autonomous freedom and divine co-causality. In: Medieval Philosophy and Theology. 2 (1992), p. 142-64.

HOERES, Walter. Der Wille als reine Vollkommenheit nach Duns Scotus, 1962. München, Anton Pustet, 1962.

Critique of the transcendental metaphysics of knowing, phenomenology and neo-scholastic philosophy. In: Aletheia. I,2 (1972), p. 353-70.

. Platonismus und Gegebenheit bei Duns Scotus. In: De doctrina Ioannis Duns Scoti. Roma, Cura Comissionis Scotisticae, Vol. I, 1968, p. 139-68.

. Sein und Reflexion. Würzburg, K. Triltsch, 1956.

MARION, Jean-Luc. Dieu sans l'Etre. Paris, Communio/FAYARD, 1982.

PICH, Roberto Hofmeister. Der Begriff der wissenschaftlichen Erkenntnis nach Johannes Duns Scotus. Bonn, Tese de Doutorado (Rheinische Friedrich-Wilhelms-Universität Bonn), 2001, 583p.

REINACH, Adolf. Über das Wesen der Bewegung (preparado para publicação por Edith Stein, com base em notas de seminário). In: REINACH, Adolf. Gesammelte Schriften. Halle, Niemeyer, 1921, p. 406-61.

SEIFERT, Josef. El hombre como persona en el cuerpo. In: Espíritu. 54 (1995), p. 129-156.

. Essence and existence. A new foundation of classical metaphysics on the basis of 'phenomenological realism', and a critical investigation of 'existentialist thomism'. In: Aletheia. I (1977), p. 17157; I/2 (1977), p. 371-459.

Essere e persona. Verso una fondazione fenomenologica di una metafisica classica e personalistica. Milano, Vita e Pensiero, 1989.

. Essere persona come perfezione pura. Il Beato Duns Scoto e una nuova metafisica personalistica. In: De Homine - Dialogo di Filosofia 11. Rom, Herder/Università Lateranense, 1994, p. $57-75$.

Gott als Gottesbeweis. Eine phänomenologische Neubegründung des ontologischen Arguments. Heidelberg, Universitätsverlag C. Winter, 1996 (2. Aufl. 2000).

Gott und die Sittlichkeit innerweltlichen Handelns. Kritische philosophische Reflexionen über den Einfluss anthropomorpher und agnostischer Gottesvorstellungen auf Ethik und Moraltheologie. In: Forum Katholische Theologie. I/1 (1985), p. 27-47.

. Karol Cardinal Karol Wojtyla (Pope John Paul II) as Philosopher and the Cracow/Lublin School of Philosophy. In: Aletheia. II (1981), p. 130-99.

Ritornare a Platone. Im Anhang eine unveröffentlichte Schrift Adolf Reinachs. Ed., preface and trans. by Giuseppe Girgenti. Collana Temi metafisici e problemi del pensiero antico. Studi e testi, Vol. 81. Milano, Vita e Pensiero, 2000.

Sein und Wesen. In: BUTTIGLIONE, Rocco und SEIFERT, Josef (Hrsg.). Philosophie und realistische Phänomenologie/Philosophy and realist phenomenology. Studien der Internationalen Akademie für Philosophie im Fürstentum Liechtenstein/Studies of the International Academy of Philosophy in the Principality Liechtenstein. Heidelberg, Universitätsverlag C. Winter, Band 3, 1996. 
The idea of the Good as the sum-total of pure perfections. A new personalistic reading of Republic VI and VII. In: REALE, Giovanni and SCOLNIKOV, Samuel (eds.). New images of Plato. Dialogues on the idea of the Good. Sankt Augustin, Academia Verlag, 2002, p. 407-24.

STEIN, Edith. Endliches und ewiges Sein. Versuch eines Aufstiegs zum Sinne des Seins. In: GERBER, L. (Hrsg.). Edith Steins Werke. 3. unver. Auflage. Freiburg, Herder, Band II, 1986

SWEENEY, Leo. Divine infinity in Greek and Medieval thought. New York/San Francisco/Bern/Frankfurt a.M./Berlin/Wien/Paris: Peter Lang, 1992.

VON HILDEBRAND, Dietrich. Ethics. $2^{\text {nd }}$. ed. Chicago, Franciscan Herald Press, 1978.

WOJTYLA, Karol. The Acting Person. Boston, Reidel, 1979 (cf. também o texto corrigido, autorizado pelo autor (e não publicado), na cópia oficial na Biblioteca da International Academy of Philosophy in the Principality Liechtenstein, Schibbogga 7 B-C, Bendern, Liechtenstein).

WOLTER, Allan B. The transcendentals and their function in the metaphysics of Duns Scotus. St. Bonaventure (N. Y.), The Franciscan Institute Publications, 1946. 